\title{
DO MARKETS CARE ABOUT CENTRAL BANK GOVERNOR CHANGES? EVIDENCE FROM EMERGING MARKETS
}

\author{
CHRISTOPH MOSER \\ AXEL DREHER
}

CESIFO WORKING PAPER NO. 2177

CATEGORY 6: MONeTARy Policy AND InTERnATIONAL FinANCE DECEMBER 2007

\footnotetext{
An electronic version of the paper may be downloaded

- from the SSRN website:

- from the RePEc website: www.SSRN.com

www.RePEc.org

- from the CESifo website:

www.CESifo-group.org/wp
} 


\title{
Do MARKeTS CARE ABOUt CENTRAL BANK GOVERNOR CHANGES? EVIDENCE FROM EMERGING MARKETS
}

\begin{abstract}
Central bank governor changes in emerging markets may convey important signals about future monetary policy. Based on a new daily data set, this paper examines the reactions of foreign exchange markets, domestic stock market indices and sovereign bond spreads to central bank governor changes. The data cover 20 emerging markets over the period 19922006. We find that the replacement of a central bank governor negatively affects financial markets on the announcement day. This negative effect is mainly driven by irregular changes, i.e., changes occurring before the scheduled end of tenure, sending negative signals about perceived central bank independence. Personal characteristics of the central banker, to the contrary, are less important for market reactions. We find no evidence that changes in the central banker's conservatism affect the reactions of the markets. Finally, market reactions are similar in countries with high and low degrees of central bank independence.
\end{abstract}

JEL Code: E58, E42, F30, G14.

Keywords: central bank governor turnover, monetary policy, emerging markets, risk premium.

\author{
Christoph Moser \\ University of Mainz \\ Department of Economics \\ Jakob-Welder-Weg 4 \\ 55128 Mainz \\ Germany \\ Christoph.Moser@uni-mainz.de
}

\author{
Axel Dreher \\ ETH Zurich \\ KOF Swiss Economic Institute \\ Weinbergstrasse 35 \\ 8092 Zurich \\ Switzerland \\ mail@axel-dreher.de
}

October 2007

Acknowledgements: We thank Ricardo Caballero, Christian Conrad, Etienne Farvaque, Martin Gassebner, Ashok Kaul, Silke Rath, Jan-Egbert Sturm, Dieter Urban, participants at the Central Banking Conference "Does Central Bank Independence Still Matter?" at the Bocconi University 2007, the Brown Bag Seminar at the University of Mainz, the Annual Meeting of the Austrian Economics Association (NOeG), the Macroeconomics Research Meeting 2007 and in particular Helge Berger for helpful comments. We thank Simon Holzhammer, Nadja Pänzer and Christoph Woodli for excellent research assistance and Jan Schopen for help in compiling the stock market and foreign exchange data. 


\title{
1 Introduction
}

\author{
"After arguing behind the scenes with his central bank governor \\ over the direction of interest rates, Prime Minister Thaksin \\ Shinawatra of Thailand [..] dismissed the banker [..] brought a \\ sharp reaction of financial markets, where it cast doubts over \\ the political independence of the Thai central bank." 1
}

The dynamic inconsistency of low-inflation monetary policy can be overcome by delegating monetary policy to independent and conservative central bankers (Rogoff, 1985). While many countries have recently granted their central banks legal independence, the experience of some countries suggests limited actual independence, with the head of the central bank frequently being replaced at short notice and outside the legal schedule. How do financial markets react to changes at the head of the central bank $?^{2}$ We expect them to react to such changes if changes convey new information about expected future monetary policy. Economic theory suggests that the inflationary bias is determined by the degree of central bank independence and the degree of the bank's conservativeness. ${ }^{3}$ Hence, if market participants' perceptions change with respect to one of these two dimensions, we will expect a change in asset prices to the extent that these prices are sensitive to inflation. There are two transmission channels: First, when the government interfered in the replacement procedure, irregular turnovers are likely to affect markets' perceptions about the central bank's independence. Second, if the perceived inflation aversion of the new head of the central bank differs from its predecessor's, this will alter expected financial market returns.

The importance of who is member of the central bank council for economic outcomes has been demonstrated in the previous literature. For example, Göhlmann and Vaubel (2007) show that education and profession of the central bank's govern-

\footnotetext{
${ }^{1}$ New York Times (2001).

${ }^{2}$ We call the heads of the central bank "governors" independent of whether their actual job title is governor, director or president.

${ }^{3}$ Eijffinger and Hoeberichts (1998) and Berger et al. (2001) explicitly model the two dimensions. Berger et al. (2001) also offer an excellent review of research on central bank independence. For a critique on Rogoff's delegation mechanism, see for instance McCallum (1995). Piga (2000) offers an overview of this strand of the literature.
} 
ing council members matter for the effectiveness in controlling inflation. Drawing on a sample of industrialized countries Kuttner and Posen (2007) conclude that markets do care about who chairs the central bank. Central bank governor changes apparently incorporate new information about the future course of monetary policy, thereby affecting exchange rates and domestic bond yields. Kuttner and Posen (2007) do not find evidence of a generic credibility problem, i.e., a systematic (at least) transitory increase in inflation expectations at the beginning of a central bank governors' tenure. However, Kuttner and Posen (2007) confine their analysis to advanced markets. In these markets, central bank governor turnovers are mostly predictable, and highly developed institutions are likely to reduce the individual governor's influence. To the contrary, appointments of central bank governors are among the most sensitive decisions for emerging market governments, as these policymakers play a crucial role in communicating with international markets (Santiso, 2003). Whether and to what extent effects similar to those observed for advanced markets exist for emerging markets has so far not been investigated. Given the extreme market reactions to changes in who is the head of the central bank in some emerging markets, this gap in the literature is quite surprising. ${ }^{4}$

This paper examines the impact of central bank governor changes on domestic and international financial markets in emerging economies. Based on a new daily data set including 20 emerging markets over the period 1992-2006, we pursue four specific objectives: First, we examine how foreign exchange rates, domestic stock market indices and sovereign bond spreads react to the announcement of a change at the helm of an emerging market central bank. Second, we test whether irregular changes affect the markets differently as compared to regular ones. Third, we offer proxies for perceived central bank independence and perceived conservativeness in order to gauge their relative impact on asset prices via changes of the inflationary bias. Finally, we test whether and to what extent central bank governor's personal characteristics affect market reactions.

\footnotetext{
${ }^{4}$ For instance, financial markets reacted sharply in Argentina (2002), when the well-respected central bank governor Mario Blejer resigned after growing policy differences between the central bank and the ministry of economy led by Roberto Lavagna.
} 
To anticipate our main results, the replacement of a central bank governor affects financial markets on the announcement day negatively. Specifically, exchange rates depreciate. The picture on domestic stock markets and foreign-currency denominated bond yields is - not surprisingly - more mixed, since these markets are at most indirectly exposed to inflation risk. According to our results, the negative effect on financial markets is mainly driven by central bank governor changes that occur before the officially scheduled end of their tenure. While financial markets seem to react to perceived changes in central bank independence, personal characteristics of the central banker are less important for market reactions. The degree of central bankers' conservatism does not matter for market reactions.

The remainder of the paper is structured as follows. Section 2 derives our hypotheses, while Section 3 describes the data set. Section 4 discusses the methodology used; Section 5 shows our results. The final section offers some concluding remarks.

\section{Hypotheses}

Evidence on the impact of who is in charge of economic policies on economic outcomes is scarce. Only very recently selected studies started analyzing the issue. Among them, Besley et al. (2005) use household survey data from India and find that differences in the performance of Indian village politicians are systematically linked to individual politicians' education. Jones and Olken (2005) find that the impact of who is the head of a government matters for economic growth. Similarly, Dreher et al. (2006) show the educational and professional background of a head of government to be decisive for the implementation of reforms. According to Moser (2006), changing the finance or economics minister increases bond spreads among a sample of twelve Latin American countries over the period 1992-2005.

Turning to central banks, Göhlmann and Vaubel (2007) provide recent empirical evidence. Their results show that education and profession of the central bank's governing council members matter for the effectiveness in controlling inflation. In a related study, Adolph (2004) documents that personal career ambitions affect the per- 
formance of central bankers. According to Gürkaynak et al. (2005), certain kinds of policy changes could affect market participants' inferences about the central bank's policy objectives. Kuttner and Posen (2007) find that markets care about who chairs the central bank. According to their results for 15 advanced economies, changing a central bank governor conveys signals about the future course of monetary policy, thereby affecting exchange rates and financial market returns. We expect the same to hold for our sample of emerging market countries. We therefore hypothesize:

Hypothesis 1a: Investors react to central bank governor changes.

Kydland and Prescott (1977) and Barro and Gordon (1983) show in their seminal papers that policymakers can not credibly commit themselves to low-inflation policy. One approach to overcome this time-inconsistency problem is to establish reputation (see for instance Backus and Driffill, 1985; Barro, 1996). While the public may not know the central bankers' preferences, policymakers' behaviour conveys some information about their characteristics and the public will adapt their expectations about inflation accordingly. Cukierman and Meltzer (1986) emphasize the importance of uncertainty about the underlying preferences of the governor. A less conservative governor ("dovish") has an incentive to mimic the behaviour of the more conservative one ("hawkish") for a while, but sooner or later it becomes optimal to behave opportunistically. Uncertainty can be expected to be highest at the beginning of a governor's tenure. In a similar vein, Schaumburg and Tambalotti (2007) and Kara (2007) state that newly-appointed central bank governors suffer from a systematic credibility problem. While the incumbent governors can credibly commit to policy during their own administration, their successors might deviate and pursue discretionary policies.

Hypothesis 1b: Investors react negatively to central bank governor changes due to a systematic credibility problem at the start of new governors' tenure.

Rogoff (1985) proposes another approach to remedy the inconsistency problem, namely the delegation of monetary policy to a conservative central bank. Eijffinger and Hoeberichts (1998) and Berger et al. (2001) develop an argument in spirit 
of Rogoff (1985). The government seeks to minimize the following loss function, representing the preferences of society:

$$
L^{\text {Gov }}=\frac{1}{2} \pi_{t}^{2}+\frac{\chi}{2}\left(y_{t}-y_{t}^{*}\right)^{2}
$$

where $\pi_{t}$ is the rate of inflation at day t, $y_{t}$ is output, $y^{*}$ denotes desired output and $\chi$ is the government's weight on output stabilization $(\chi>0)$. In contrast to that, the loss function of the central banker is expected to differ in one important aspect:

$$
L^{C B}=\frac{1+\epsilon}{2} \pi_{t}^{2}+\frac{\chi}{2}\left(y_{t}-y_{t}^{*}\right)^{2}
$$

where $\epsilon$ denotes the additional inflation aversion of the central bank governor. Furthermore, Eijffinger and Hoeberichts (1998) argue that central bankers' preferences only matter to the extent that they can pursue monetary policy without (much) government interference. This can be captured in the following way:

$$
M_{t}=\gamma L^{C B}+(1-\gamma) L^{G o v}
$$

where $\gamma$ and $M_{t}$ denote the degree of central bank independence and monetary policy, respectively. Assuming that output is determined by a simplified Lucas supply function and assuming rational expectations, inflation turns out to be:

$$
\pi_{t}=\chi y_{t}^{*}-\frac{\chi}{\chi+1} \mu_{t} \text { and } \pi_{t}=\frac{\chi}{1+\gamma \epsilon} y_{t}^{*}-\frac{\chi}{1+\gamma \epsilon+\chi} \mu_{t}
$$

The equation on the left (right) side represents the inflation outcome without (with) delegation of monetary policy. Comparing these two outcomes, it becomes clear that it is the product of central bank independence and conservativeness that matters for monetary policy. We will label this product "effective conservatism" of monetary policy. For positive values of $\gamma$ and $\epsilon$ any increase of either the degree of central bank independence or the central bank governor's conservativeness will ceteris paribus decrease the inflationary bias. Figure 1 graphically shows that the same level of monetary policy can be achieved through various combinations of the two dimensions. 


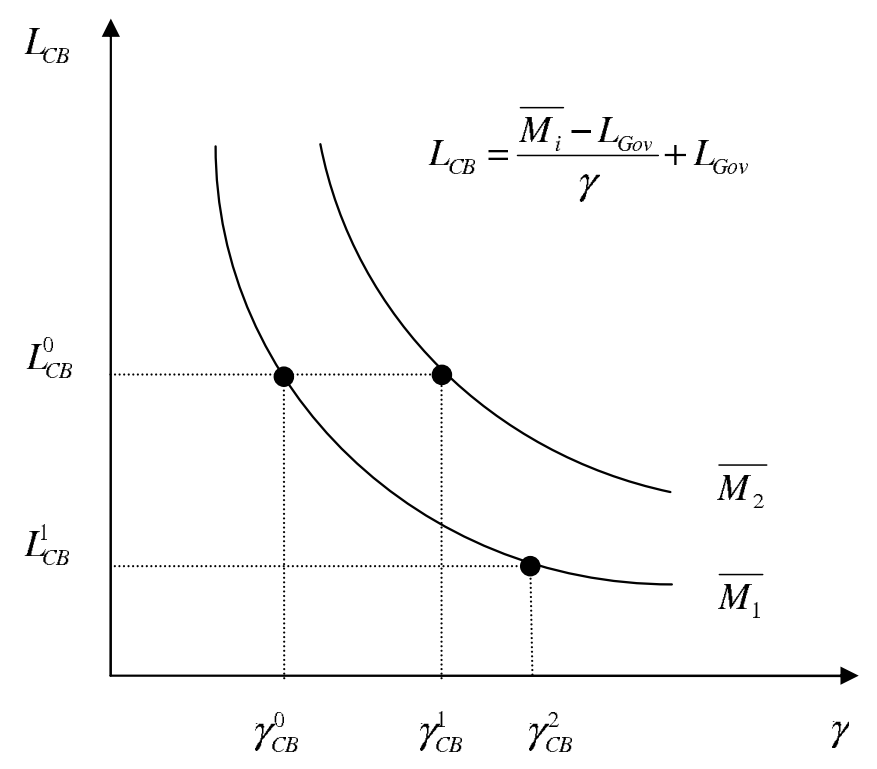

Figure 1: Effective Conservatism

Following this line of argumentation, changing the central bank governor might impact financial market expectations (at least) along these two dimensions. First, changes at the head of the central bank may carry signals about the future stance of the incumbent government on the central bank's independence. If the central bank governors' resignation is politically motivated and/or the incoming governors lack political independence, financial markets are likely to react negatively. Second, a newly appointed central bank governors' attitude towards conservative monetary policy might deviate from those of his predecessor. Depending on whether markets expect the new incumbent to be more financially conservative than the old one, market reactions should be positive. We hypothesize:

Hypothesis 2a: Investors react to changes in perceived conservatism.

And in particular:

Hypothesis 2b: Investors react negatively to irregular changes, as a decrease in perceived central bank independence decreases effective conservatism.

We employ various characteristics of outgoing and newly appointed governors to distinguish between these two channels. Furthermore, the extent to which international 
investors react to central bank governor changes may depend on the institutional setting of the central bank. More specifically, the independence of a highly independent central bank might not be perceived to be in danger after irregular changes. On the other hand, in these countries, in particular, political interference in the turnover of a government will trigger substantial response, as such interference arguably has a bigger impact on perceptions about the bank's independence. Therefore:

Hypothesis 3: Investors' reactions to central bank governor changes depend on the institution's legal framework.

Turning to appointments of new governors, we distinguish between incoming governors educated in the US or UK and those without such education. On average, we expect US- or UK-educated governors to be perceived as more conservative and credible than those without such education, since investors can better anticipate their preferences. ${ }^{5}$ We also separately analyze incoming governors with a history in their central bank (insiders) and those without (outsiders). Adolph (2004) finds that financial sector and finance ministry veterans are associated with lower inflation than other government bureaucrats and central bank staff.

Hypothesis 4: Markets react to personal characteristics of the incoming central bank governor.

Finally, we separately analyze anticipated and unanticipated resignations, since we would expect that the surprise content and consequently the market reaction is more pronounced for unanticipated events:

Hypothesis 5: Unanticipated resignations lead to larger market reactions than anticipated ones.

Clearly, governor changes might affect exchange markets, stock markets and bond markets to a different degree - and even in different directions. We address each of

\footnotetext{
${ }^{5}$ A similar argument is put forward by Santiso (2003).
} 
these markets in turn. We implicitly assume that the semi-strong form of the efficient market hypothesis holds. ${ }^{6}$ Under this hypothesis security prices are assumed to reflect all public information and to adjust swiftly to the arrival of new public information. In this vein, a central bank governor change is expected to affect asset prices, if and only if, the change contains new information about the future course of monetary policy. If markets fully anticipate the event or an information leakage occurs, prices will not react at all. The underlying null hypothesis for all our hypotheses is thus that central bank governor changes do not contain any relevant news about the future monetary policy course.

Foreign Exchange Markets

Following Kuttner and Posen (2007) our starting point for analyzing the impact of central bank governor changes on the exchange rate is the uncovered interest rate parity:

$$
E_{t} \Delta e_{t+1}=i_{t}^{*}-i_{t}
$$

with $e$ being the log of the foreign exchange rate (foreign currency/domestic currency), $i$ being the domestic interest rate, and where $i^{*}$ is the foreign interest rate. Solving forward, we obtain

$$
e_{t}=E_{t}\left[\sum_{s=0}^{T-1}\left(i_{t+s}-i_{t+s}^{*}\right)+e_{T}\right]
$$

where $e_{T}$, the nominal exchange rate at some future date $\mathrm{T}$, can be thought of as the expected equilibrium exchange rate, determined by - for large enough values of $\mathrm{T}$ - purchasing power parity (PPP). Hence, expected changes in monetary policy can affect the foreign exchange rate either through expected changes in the nominal interest rate differentials and/or changes in the expected long-run exchange rate. For positive (negative) changes in effective conservatism, i.e. either an increase in central bank independence or conservatism, we will expect the foreign exchange rate to appreciate (depreciate). This can materialize either through a rise in the interest rate differential and/or by reducing the expected future price level.

\footnotetext{
${ }^{6}$ Even though empirical evidence is still ambiguous, the semi-strong form of efficient market hypothesis enjoys wide acceptance.
} 


\section{Domestic Stock Markets}

The effect of a change in the expected monetary policy on stock markets is less obvious than for the exchange markets. Stock market prices can be valuated in the context of present-value models. Following Campbell et al. (1997) the stock price can be expressed as the expected value of future dividends (D) out to the infinite future, discounted at a constant rate $(\mathrm{R})$.

$$
P_{t}=E_{t}\left[\sum_{i-1}^{\infty}\left(\frac{1}{1+R}\right)^{i} D_{t+i}\right] \text {. }
$$

For this classic "Gordon growth model," changing monetary policy expectations can potentially affect stock prices through two different channels. Policy expectations might simply affect the discount rate or more subtly affect the expected future dividend stream. While the expected coefficient for a decrease in effective conservatism might be rather positive than negative, Fama (1981) and Schwert (1981), for instance, find a negative relation between inflation and stock returns. Alternatively, one could bear analogy to Caballero and Krishnamurthy (2004), who argue that a perceived worsening of an incumbent government's (fiscal) responsibility may lower the valuation of the country's asset in an environment of limited financial depth. To sum up, while based on a pure inflation argument the expected stock market effects to a central bank governor change are ambiguous, on a more general ground, financial investors may demand a higher risk premium for perceived bad policy management.

\section{Foreign-currency Denominated Bond Markets}

The classical approach to model sovereign bond yields dates back to Edwards (1984), denoting the spread as a function of the probability of default (pd) and the risk-free interest rate $\left(i^{*}\right)$ :

$$
s=\frac{p d}{1-p d}\left(1+i^{*}\right)
$$

Since our bond data is restricted to foreign-currency denominated public or publicly guaranteed debt, the default risk is concerned with the risk that a government defaults on or not fully honours its bond contracts to foreigners (Obstfeld and Rogoff, 1996). News affecting the sovereign's default probability is expected to alter 
sovereign bond spreads. ${ }^{7}$ Foreign-currency denominated bonds are not sensitive to changing inflation expectations and any possible transmission channel is of indirect nature via the changing perception of the probability of default. ${ }^{8}$ Alternatively, one can argue once more in line with Caballero and Krishnamurthy (2004). If investors dislike the way the central bank governor change is induced, for instance due to political interference in an otherwise independent central bank, bond prices are expected to fall.

\section{Data}

Our analysis is based on several types of data. The selection of countries is constrained by the availability of financial market data on a daily basis. We focus on countries where reliable foreign exchange market, stock market and bond market data is available. The resulting sample spans the period 1992 to 2006 for the following 20 emerging markets: Argentina, Brazil, Chile, China, Colombia, Egypt, Hungary, Malaysia, Mexico, Morocco, Pakistan, Peru, Philippines, Poland, Russia, South Africa, South Korea, Thailand, Turkey and Venezuela. The number of observations varies, however, among our estimation samples.

A major pillar of our daily dataset is the unique sample on changes of central bank governors. We have drawn on various sources. The bulk of our data is derived from full-text analysis on the Economist, the Wall Street Journal and the Financial Times through the online data base provider LexisNexis. As Santiso (2003) points out, these newspapers are unchallenged in the financial community and contribute to shaping public attention and categories of thought. "[..] for professionals working

\footnotetext{
${ }^{7}$ More precisely, adverse news on the country's creditworthiness leads to a decline in bond prices and hence an increase in yields-to-maturity and bond spreads, respectively.

${ }^{8}$ We can think of two different channels how central bank governor changes impact the perceived probability of default. First, if the change at the head of the central bank is interpreted as a sign of political interference, international investors will be expected to demand a higher sovereign spread. A less independent central banker (for any given level of conservatism) makes it more likely that fiscal policy ultimately dominates monetary policy, driving up public debt and the perceived probability of default. Second, a more conservative response to excess inflation raises (for given level of independence) expected real interest rates, reducing expected investment and, hence, expected growth rates. This in turn will worsen the debt sustainability situation, which is expected to increase the probability of default and, hence, the sovereign bond spread.
} 
in emerging markets, the Financial Times is considered the major source of information" (Santiso, 2003, p. 129). These three financial newspaper sources are backed by other press sources available through LexisNexis, if necessary. Overall, this procedure yields 65 observations, comprising 44 resignations and 21 appointments at the head of a central bank. Appendix 1 shows the number of observations per country in our data set, with Argentina and Brazil by far showing the greatest number of turnovers over the sample period. ${ }^{9}$

We also collected data on additional characteristics of the central bank governors in our sample. Moreover, we have cautiously sought to infer from newspaper articles whether and to what extent the respective change has been anticipated. If the change was largely anticipated by the markets, we would expect a softer reaction in bond spreads. Regarding appointments, we distinguish between insiders and outsiders. While the former have shown at least some central bank experience before being designated as central bank governor, the latter have not. We also gathered information on whether the respective governor has been educated in the US or UK. While we can be confident about the hard facts, i.e., the name and position of the governor and his date of departure, the soft facts about the surprise content should be interpreted more cautiously. The governor characteristics are completed with data on the partisanship of the nominating government, drawn from the Database of Political Institutions (see Beck et al., 2001). Appendix 4 gives a precise listing of the timing and nature of central bank governor changes among our sample. A brief summary for the reasons leaving the central bank is also given.

Regarding sovereign bond spread, we rely on index data provided by the U.S. investment bank J.P. Morgan. These country indices are closely watched indicators for perceived country risk in emerging markets. The yield spread or bond spread can be interpreted as a default premium charged by investors above the risk-free interest rate. It is expressed in basis points and is calculated as the yield difference between the (basket of country) emerging market bond(s) and a comparable U.S. bond. Specifically, we use the Emerging Markets Bond Index (EMBI), the Emerg-

\footnotetext{
${ }^{9}$ To foreshadow the empirical results, neither the exclusion of Brazil nor Argentina changes the results qualitatively.
} 
ing Markets Bond Index Plus (EMBI+) and the Emerging Markets Bond Global (EMBIG). ${ }^{10}$ These sovereign bond spread indices are weighted averages of externalcurrency-denominated individual bonds issued by a particular country. Spreads on emerging market bonds most likely represent a mixture of spreads stemming from credit risk and liquidity risk. Only sovereign bonds that comply with well-defined liquidity requirements are eligible for J.P. Morgan's bond indices. ${ }^{11}$ As Sy (2001) notes, the spreads have consequently little or similar liquidity risk premia. For this reason we can assume that the impact of liquidity risk on the total country risk premium is negligible. ${ }^{12}$ Appendix 2 gives an exact listing of the data available. Appendix 3 provides summary statistics on the respective dependent and control variables.

Turning to stock markets, we use local market indices provided by Morgan Stanley Capital International Inc. (MSCI). The MSCI data used here are daily returns of indices, excluding dividends, and measured in local currency. The indices measure market performance for selected securities, capturing the market capitalization weighted return of all constituents included. For most countries among our sample, data are available from January 1988 to December $2006 .^{13}$

Regarding exchange rate data, finally, we draw from Bloomberg. Daily foreign exchange rates vis-à-vis the U.S. dollar are employed, whereby an increasing foreign exchange indicator means a depreciation of the domestic currency vis-à-vis the U.S. dollar.

We also employ a number of control variables. We control for US financial market indicators using the yield of 10-year US Treasury bonds and 3-month US Treasury bills. Both variables are widely used to control for international liquidity. Finally, we

\footnotetext{
${ }^{10}$ Henceforth, the notion EMBI is used synonymously for EMBI, EMBI+ and EMBIG. We mainly rely on the EMBI+ due to its relatively large coverage in Latin America, its liquidity requirements and its up to date record. Bond spread data from the early 1990s are obtained from EMBI. For Chile, Dominican Republic and Uruguay only EMBIG data is available.

${ }^{11}$ Instruments in the EMBI+ have to exceed the issue amount of USD 500 millions and must be available and liquid. The average bid/offer spread has to be smaller than 1.5 basis points.

${ }^{12}$ Strictly speaking, the interest rate (in local currency) is equal to the risk free rate (in "hard" currency) plus the total country (risk) premium. The latter consists of the currency (risk) premium, the pure default (risk) premium and the jurisdiction premium (see for instance Peter (2005).

${ }^{13}$ Note that MSCI returns are closely correlated with the returns of the respective country indices (Pantzalis et al. 2000).
} 
add the volatility index (VIX) of the Chicago Board Options Exchange (CBOE) as a proxy for financial market uncertainty. The VIX measures the implied volatility from option contracts on the Standard and Poor's 100 (S\&P 100) index. First suggested by Duecker (1999), this index gives an idea about the market expectation of the volatility of the S\&P 100 in the subsequent month. In this sense, the index can be interpreted as a forward looking indicator on global risk aversion. ${ }^{14}$

\section{Method}

To test the effects of central bank governor changes on financial markets we employ three different dependent variables. We gauge the effect of the announcement of the departure of the central bank governor on sovereign bond spreads, stock market indices and the foreign exchange rates vis-à-vis the U.S. dollar. ${ }^{15}$

We start with three simple tests. First, we evaluate whether the mean change of our variables of interest $(\Delta y)$ over the sample period equals their mean change on the event days. Our second test follows Kuttner and Posen (2007) and also refers to the average market reaction to news announcements. As the volatility of our dependent variables varies over time and country, we normalize $\Delta y$ by subtracting off the average change $\overline{\Delta y}$ over the 90 days preceding the announcement and dividing by its estimated standard deviation $\sigma$ over the same period of time. The statistic we use is thus $z_{i} \equiv\left(\Delta y_{t}-\overline{\Delta y}\right) / \sigma$.

Under the null hypothesis that news regarding the change of the central bank governor contain no relevant information, $\Delta y$ follows the pre-announcement distribution with zero mean and unit variance (Kuttner and Posen, 2007). We test whether the average change in our normalized dependent variables significantly differs from zero on days where the replacement of a governor is announced. The average dependent variables are approximately distributed as normal variables with variance $1 / \mathrm{N}$, with $\mathrm{N}$ being the number of events in our sample.

\footnotetext{
${ }^{14}$ The same index is used in a study on sovereign bond spread indices by the IMF (2001).

${ }^{15}$ The fact that we use daily data does not allow us to control for classical macroeconomic determinants of bond spreads or foreign exchange rates, like for instance the gross domestic product or exports.
} 
As Kuttner and Posen (2007) note, positive and negative reactions to new governors might cancel themselves out, biasing market reactions downward. As an alternative test, they therefore propose a method introduced by Fisher (1941), combining independent hypotheses into a single test statistic. According to Fisher, -2 times the $\log$ of a p-value follows the $\chi_{2}^{2}$ distribution, where the sum of $\chi_{2}^{2}$ distributed variables follows the same distribution. Under the null hypothesis $-2 \sum_{i-1}^{N} \ln p_{i}$ is distributed as $\chi_{2 N}^{2}$, with $p_{i}$ being the p-values of the individual tests. As one major disadvantage with this method, the result is very sensitive regarding outliers. Specifically, a low overall p-value can be driven by just one significant event, with a p-value close to zero. Still, we apply this method as our third preliminary test. As a next step, we provide panel data analysis. All regressions control for day-of-the-week effects. Our baseline regression (equation 1) is estimated by pooled OLS with robust standard errors clustered at the country level ${ }^{16}$ and takes the following form:

$$
\Delta \mathrm{Y}_{\mathrm{i}, \mathrm{t}}=\alpha+\lambda \Delta \mathrm{Y}_{\mathrm{i}, \mathrm{t}-1}+\beta \mathrm{RESIGN}_{\mathrm{i}, \mathrm{t}}+\gamma \mathrm{APPOINT}_{\mathrm{i}, \mathrm{t}}+\eta \Delta \mathrm{X}_{\mathrm{i}, \mathrm{t}}+\nu_{\mathrm{w}} \mathrm{D}_{\mathrm{w}}+\epsilon_{\mathrm{i}, \mathrm{t}},
$$

where the subscripts $\mathrm{i}$ and $\mathrm{t}$ indicate country and time, respectively. $Y_{i, t}$ is the respective dependent variable denoted in log-differences, namely the MSCI stock market indices, the foreign exchange rates vis-à-vis the U.S. dollar and the EMBI bond spreads. The dependent variable also enters the equation lagged by one period - we return to this below. Our coefficients of interest are $\beta$ and $\gamma$, accounting for the impact of resignations $R E S I G N_{i, t}$ and new appointments $A P P O I N T_{i, t}$ at the head of the central bank. The variable is one on the day of the change $(\mathrm{t})$. The error term $\epsilon_{i, t}$ is assumed to be an independently distributed random variable with mean zero and variance $\sigma_{i, t}^{2}$. We employ dummy variables $D_{w}$, running from Monday to Thursday, in order to control for week-day-effects.

The matrix $X_{i, t}$ includes up to three of the following US financial market indicators available on a daily basis that might affect emerging market financial indicators, namely the volatility index (VIX) and U.S. interest rates (10-year U.S.

\footnotetext{
${ }^{16}$ Kaminsky and Schmukler (2002) and Andritzky et al. (2007) employ a similar empirical strategy. We do not include fixed country effects as they are not jointly significant at conventional levels. Our key results are not changed by their exclusion.
} 
Treasury bonds and 3-month U.S. T-bills). We employ log changes of the volatility index, proxying for time varying risk appetite of international investors. We expect a positive (negative) coefficient for the volatility variable on bond spreads and foreign exchange rates (stock markets). Economic theory suggests a positive effect of U.S. interest rates on emerging market bond spreads. A rise in U.S. interest rates increases the debt burden for an emerging market government and, hence, negatively affects the capacity to repay its debt. ${ }^{17}$ We thus control for the log-difference of 10-year US Treasury yields and log changes of 3-month US T-bills. ${ }^{18}$

Finally, one specific issue arises in the case of foreign exchange rates. By definition, fixed exchange rate regimes do not allow for daily market reactions in case of the announcement of the central banker change. For this reason, we interact the resignation or appointment variable with a dummy variable that takes the value of 1 in case of a flexible exchange rate (or at least not fully pegged exchange rate) and which is 0 otherwise. ${ }^{19}$

In a second step, we introduce an interaction term between the resignation dummy and an event dummy for irregular central bank governor changes.

$$
\begin{aligned}
& \Delta \mathrm{Y}_{\mathrm{i}, \mathrm{t}}=\alpha+\lambda \Delta Y_{i, t-1}+\beta_{1} R E S I G N_{i, t}+\beta_{2} R E S I G N_{i, t} * I R R E G_{i, t}+ \\
& +\gamma A P P O I N T_{i, t}+\eta \Delta X_{i, t}+\nu_{w} D_{w}+\epsilon_{i, t},
\end{aligned}
$$

where $I R R E G_{i, t}$ is a dummy variable that takes the value of 1 , if the central bank governor change occurred before the expiration of the central bank governor tenure and 0 otherwise. If investors' reaction to irregular events is markedly different from the overall resignation effect, we expect a significant coefficient for the interaction term. Following Kuttner and Posen (2007), we also classify cases in which the incumbent governor was eligible for reappointment, but did not receive it, as irregular. ${ }^{20}$ We suggest that irregular central bank governor changes can be interpreted as a

\footnotetext{
${ }^{17}$ See Kamin and von Kleist (1999) and Arora and Cerisola (2001) for further discussion.

${ }^{18}$ Defined as $100 * \log \left(1+i_{t}^{U S}\right)$.

${ }^{19}$ Since common exchange rate classifications are not available on a daily basis, we simply label an exchange rate regime as flexible as long as at least some market reactions are observable in the weeks around the event day.

${ }^{20}$ These kinds of irregular changes constitute a very small number of all irregular resignations.
} 
certain degree of political interference of the government in the central bank, since most of them take place way before the scheduled expiration day. ${ }^{21}$ Hence, irregular events can be expected to alter perceived central bank independence, which is according to Eijffinger and Hoeberichts (1998) and Berger et al. (2001) - one of the two key determinants of inflationary bias.

Third, we seek to control for the second important dimension of the inflationary bias, namely the perceived inflation aversion of the new head of the central bank. If the inflation preferences of the new central bank governor differ from its predecessor's, this is expected to alter, ceteris paribus, financial market returns. Obviously, the inflation aversion of the new central bank governor is not observable on the announcement day. Hence, we follow Berger, H. and U. Woitek (2005) and Adolph (2004) in constructing our proxy. We use the partisan preferences of the government nominating the central banker and assume a change in inflation aversion of the new central bank governor, when the governor has been nominated by a different government than the previous one. Our definition of partisanship relies on the Database of Political Institutions from the World Bank (see Beck et al., 2001). Our equation changes to:

$$
\begin{aligned}
& \Delta \mathrm{Y}_{\mathrm{i}, \mathrm{t}}=\alpha+\lambda \Delta Y_{i, t-1}+\beta_{1} R E S I G N_{i, t}+\beta_{2} R E S I G N_{i, t} * I R R E G_{i, t}+ \\
& +\quad \beta_{3} R E S I G N_{i, t} * \operatorname{IRREG} G_{i, t} * \operatorname{PARTISAN}_{i, t}+\gamma A P P O I N T_{i, t}+ \\
& +\eta \Delta X_{i, t}+\nu_{w} D_{w}+\epsilon_{i, t},
\end{aligned}
$$

where PARTISAN ${ }_{i, t}$ is a dummy variable that takes the value one when the nominating government's partisanship has changed from the previous one.

To investigate how far the level of central bank independence matters for market reactions to the announcement of central bank governor changes in emerging markets we draw on work from Cukierman (1992) and Arnone et al. (2007). Building on specification (2) we estimate the average announcement effect separately for two

\footnotetext{
${ }^{21}$ We abstain from distinguishing between "voluntary" and "forced" resignation before the end of tenure as this information cannot be properly inferred from newspaper articles. In many instances politicians and central bankers alike resign ostensibly "for personal reasons." But as a matter of fact they would have been forced out of office otherwise. By resigning voluntarily, they are allowed to save their face.
} 
sub samples, containing countries with below and above average legal central bank independence over our sample period, respectively. The data on central bank independence is available for two periods in time, the late 1980s and 2003. We use the median of their average overall values over those periods.

Finally, we investigate whether and to what extent personal characteristics of central bank governors matter for market reactions. We estimate

$$
\begin{aligned}
\Delta \mathrm{Y}_{\mathrm{i}, \mathrm{t}} & =\alpha+\lambda \Delta Y_{i, t-1}+\beta \operatorname{RESIGN} N_{i, t}+\gamma A P P O I N T_{i, t} * C H A R A C T_{i, t}+(4) \\
& +\eta \Delta X_{i, t} \nu_{w} D_{w}+\epsilon_{i, t}
\end{aligned}
$$

with $C H A R A C T_{i, t}$ representing dummies for the appointment of insiders or, respectively, governors who have been educated in the UK or US.

As one potential caveat to this analysis, central bank governors might be dismissed as a consequence of economic crises, giving rise to endogeneity. When governors are dismissed due to economic shocks, market reactions might reflect these shocks rather than the exogenous change in who governs the central bank. While this argument appears reasonable for quarterly or yearly data, endogeneity is unlikely to be an issue when data frequency is daily, as is the case in our study. Even if the governor is fired as a consequence of macroeconomic crises, such crises usually unfold over a longer period of time, so daily data can still be used to identify the causal impact of the turnover itself on market reactions. Endogeneity is thus unlikely to be an issue here. ${ }^{22}$

\section{Results}

Table 1 reports the average market reactions to the announcements of a change in the central bank governor, the number of events, and the p-value associated with the hypothesis that the event has no effect on financial markets.

As can be seen, the exchange rate and bond spreads do indeed react to resigna-

\footnotetext{
${ }^{22}$ True, the effect of a turnover could differ between crises and non crises periods. We do not have daily crises data to investigate this hypothesis.
} 


\begin{tabular}{|c|c|c|c|c|}
\hline Sample & & $\begin{array}{c}\text { Exchange } \\
\text { rate }\end{array}$ & $\begin{array}{l}\text { Bond } \\
\text { yield }\end{array}$ & $\begin{array}{c}\text { Stock } \\
\text { price LC }\end{array}$ \\
\hline \multirow{4}{*}{ All resignations } & 90 days avg. & 0.002 & -0.0002 & 0.001 \\
\hline & Event day & 0.010 & 0.007 & -0.005 \\
\hline & $\mathrm{N}$ & 41 & 44 & 44 \\
\hline & p-value & 0.099 & 0.083 & 0.151 \\
\hline \multirow[t]{3}{*}{ Irregular resignation } & Event day & 0.014 & 0.008 & -0.007 \\
\hline & $\mathrm{N}$ & 32 & 34 & 34 \\
\hline & p-value & 0.068 & 0.147 & 0.124 \\
\hline \multirow[t]{3}{*}{ Regular resignation } & Event day & -0.002 & 0.007 & 0.002 \\
\hline & $\mathrm{N}$ & 9 & 10 & 10 \\
\hline & $\mathrm{p}$-value & 0.017 & 0.307 & 0.871 \\
\hline \multirow[t]{3}{*}{ Anticipated resignation } & Event day & -0.005 & 0.008 & -0.001 \\
\hline & $\mathrm{N}$ & 7 & 7 & 7 \\
\hline & p-value & 0.052 & 0.308 & 0.778 \\
\hline \multirow[t]{4}{*}{ Unanticipated resignation } & Event day & 0.009 & 0.010 & -0.004 \\
\hline & $\mathrm{N}$ & 13 & 16 & 16 \\
\hline & p-value & 0.515 & 0.037 & 0.602 \\
\hline & 90 days avg. & 0.002 & 0.002 & -0.001 \\
\hline \multirow[t]{3}{*}{ All appointments } & Event day & -0.007 & -0.003 & 0.016 \\
\hline & $\mathrm{N}$ & 20 & 21 & 21 \\
\hline & p-value & 0.410 & 0.537 & 0.123 \\
\hline \multirow[t]{3}{*}{ Appointment of insider } & Event day & -0.014 & 0.000 & 0.007 \\
\hline & $\mathrm{N}$ & 8 & 9 & 9 \\
\hline & p-value & 0.582 & 0.400 & 0.437 \\
\hline \multirow[t]{3}{*}{ Appointment of outsider } & Event day & -0.004 & -0.006 & 0.027 \\
\hline & $\mathrm{N}$ & 10 & 10 & 10 \\
\hline & p-value & 0.232 & 0.301 & 0.200 \\
\hline \multirow[t]{3}{*}{ US based education } & Event day & 0.003 & -0.012 & 0.030 \\
\hline & $\mathrm{N}$ & 9 & 10 & 10 \\
\hline & p-value & 0.880 & 0.365 & 0.178 \\
\hline \multirow[t]{3}{*}{ No US based education } & Event day & -0.020 & 0.006 & 0.004 \\
\hline & $\mathrm{N}$ & 9 & 9 & 9 \\
\hline & p-value & 0.367 & 0.791 & 0.450 \\
\hline
\end{tabular}


tions of central bank governors, with coefficients significant at the ten percent level. Domestic stock prices, to the contrary, are not significantly affected by resignations. According to the results, the exchange rate depreciates, while bond spreads increase. The table also shows that appointments of new governors do not significantly affect the markets.

The further rows of Table 1 differentiate resignations and appointments according to the various characteristics of the governors and events in our sample. Focusing on irregular resignations (based on 32 observations), we do find that the exchange rate depreciates by more than 1 percent, on average, on the announcement day. To the contrary, the exchange rate appreciates as a consequence of the nine regular resignations among our sample. This might imply that incoming central bank governors are on average perceived to be more conservative than their predecessors.

Comparing anticipated resignations with unanticipated ones, the results show no obvious pattern. Clearly, anticipated events should already be priced in the markets, according to the efficient market hypothesis. Still, anticipated exits lead to an appreciation of the exchange rate of 0.5 percent. This small - significant - effect might stem from a perceived change in conservatism, since half of the anticipated events are regular events that also involve a change in the partisanship of the nominating government. Regarding bond spreads, the result is more in line with our a priori expectations. Bond spreads increase by 1 percent following an unanticipated exit.

Table 2 shows the value of the z-statistics with their significances. Again, the results show some interesting patterns. Regarding the resignation of central bank governors, the overall result is consistent with those reported in Table 1, with resignations significantly depreciating the exchange rate and increasing bond spreads. Moreover, stock prices decrease, at the five percent level of significance. Again, the results show that the effect on the exchange rate is driven by irregular events, while - this time - regular resignations increase bond spreads at the ten percent level of significance. Again, anticipated resignations lead to an appreciation of the exchange rate with respect to the US Dollar, at the five percent level of significance. Also at the five percent level, unanticipated exits increase bond spreads, while irregular ones 


\begin{tabular}{|c|c|c|c|c|}
\hline Sample & & $\begin{array}{c}\text { Exchange } \\
\text { rate }\end{array}$ & $\begin{array}{l}\text { Bond } \\
\text { yield }\end{array}$ & $\begin{array}{c}\text { Stock } \\
\text { price LC }\end{array}$ \\
\hline \multirow[t]{2}{*}{ All resignations } & $\begin{array}{l}\text { Avg. Change } \\
\mathrm{N}\end{array}$ & $\begin{array}{c}0.258 \\
41\end{array}$ & $\begin{array}{c}0.326 \\
44\end{array}$ & $\begin{array}{c}-0.303 \\
44\end{array}$ \\
\hline & p-value & 0.099 & 0.031 & 0.044 \\
\hline Irregular resignation & $\begin{array}{l}\text { Avg. Change } \\
\text { N } \\
\text { p-value }\end{array}$ & $\begin{array}{c}0.461 \\
32 \\
0.009\end{array}$ & $\begin{array}{c}0.259 \\
34 \\
0.131\end{array}$ & $\begin{array}{c}-0.382 \\
34 \\
0.026\end{array}$ \\
\hline Regular resignation & $\begin{array}{l}\text { Avg. Change } \\
\text { N } \\
\text { p-value }\end{array}$ & $\begin{array}{c}-0.475 \\
9 \\
0.154\end{array}$ & $\begin{array}{l}0.551 \\
10 \\
0.081\end{array}$ & $\begin{array}{c}-0.036 \\
10 \\
0.909\end{array}$ \\
\hline Anticipated resignation & $\begin{array}{l}\text { Avg. Change } \\
\mathrm{N} \\
\text { p-value }\end{array}$ & $\begin{array}{c}-0.876 \\
7 \\
0.020\end{array}$ & $\begin{array}{c}0.330 \\
7 \\
0.338\end{array}$ & $\begin{array}{c}0.036 \\
7 \\
0.924\end{array}$ \\
\hline Unanticipated resignation & $\begin{array}{l}\text { Avg. Change } \\
\mathrm{N} \\
\text { p-value }\end{array}$ & $\begin{array}{c}0.144 \\
13 \\
0.604\end{array}$ & $\begin{array}{c}0.624 \\
16 \\
0.013\end{array}$ & $\begin{array}{c}-0.299 \\
16 \\
0.232\end{array}$ \\
\hline All appointments & $\begin{array}{l}\text { Avg. Change } \\
\mathrm{N} \\
\text { p-value }\end{array}$ & $\begin{array}{l}3.036 \\
20 \\
0.000\end{array}$ & $\begin{array}{c}-0.318 \\
21 \\
0.145\end{array}$ & $\begin{array}{c}0.732 \\
21 \\
0.001\end{array}$ \\
\hline Appointment of insider & $\begin{array}{l}\text { Avg. Change } \\
\mathrm{N} \\
\text { p-value }\end{array}$ & $\begin{array}{c}8.068 \\
8 \\
0.000\end{array}$ & $\begin{array}{c}-0.335 \\
9 \\
0.315\end{array}$ & $\begin{array}{c}0.493 \\
9 \\
0.139\end{array}$ \\
\hline Appointment of outsider & $\begin{array}{l}\text { Avg. Change } \\
\text { N } \\
\text { p-value }\end{array}$ & $\begin{array}{c}-0.430 \\
10 \\
0.174\end{array}$ & $\begin{array}{c}-0.350 \\
10 \\
0.319\end{array}$ & $\begin{array}{l}1.078 \\
10 \\
0.001\end{array}$ \\
\hline US based education & $\begin{array}{l}\text { Avg. Change } \\
\mathrm{N} \\
\text { p-value }\end{array}$ & $\begin{array}{c}6.880 \\
9 \\
0.000\end{array}$ & $\begin{array}{c}-0.459 \\
10 \\
0.147\end{array}$ & $\begin{array}{c}1.105 \\
10 \\
0.000\end{array}$ \\
\hline No US based education & $\begin{array}{l}\text { Avg. Change } \\
\mathrm{N} \\
\text { p-value }\end{array}$ & $\begin{array}{c}-0.119 \\
9 \\
0.721\end{array}$ & $\begin{array}{c}-0.175 \\
9 \\
0.600\end{array}$ & $\begin{array}{c}0.462 \\
9 \\
0.166\end{array}$ \\
\hline $\begin{array}{l}\text { Note: The table evaluates whe } \\
\text { the sample period, normalized } \\
\text { ceding the announcement and } \\
\text { period of time, equals their me } \\
\text { change in our normalized depe } \\
\text { the replacement of a governor }\end{array}$ & $\begin{array}{l}\text { er the mean cha } \\
\text { y subtracting off } \\
\text { ividing by its est } \\
\text { n change on the } \\
\text { dent variables sig } \\
\text { announced. }\end{array}$ & $\begin{array}{l}\text { ge of our vari } \\
\text { the average ch } \\
\text { mated standar } \\
\text { vent days. We } \\
\text { nificantly diffe }\end{array}$ & $\begin{array}{l}\text { bles of int } \\
\text { inge over } \\
\text { deviatio } \\
\text { test whet } \\
\text { from zer }\end{array}$ & $\begin{array}{l}\text { st }(\Delta y) \text { over } \\
90 \text { days pre- } \\
\text { over the same } \\
\text { the average } \\
\text { n days where }\end{array}$ \\
\hline
\end{tabular}


decrease stock prices (by almost 4 percent).

Turning to appointments of new governors, the results substantially deviate from those reported in Table 1. The results show that new appointments lead - on average - to a depreciation of the exchange rate and an increase in stock prices, while bond spreads are not affected. Distinguishing appointments of insiders from those without a history in the central bank shows that the appointment of an insider leads to a depreciation of the exchange rate, at the one percent level of significance. This result can be interpreted in light of Adolph (2004), who finds that central bank governors who have been former central bank officials are associated with higher inflation than, for instance, former private bankers.

As Table 1 also shows, appointing an outsider does, to the contrary, not significantly affect the exchange rate. Moreover, the appointment of a central bank governor with US- or UK-based education increases stock prices, at the one percent level of significance. Surprisingly, however, the appointment of central bank governors educated in the US also depreciates the exchange rate. This might be due to the fact that especially Latin American governments - well-known for their lack of central bank independence - picked US trained economists to run their central banks over the sample period.

The results of the Fisher test - aggregating the p-values of the test statistics for the individual events - are reported in Table 3. As outlined above, we do not put much faith in them, but merely report them to make our results comparable with Kuttner and Posen (2007). To some extent, the results are again in line with those reported previously. To summarize the broad picture, resignations only seem to affect the exchange rate. Irregular resignations depreciate the exchange rate at the one percent level of significance, and so do unanticipated ones. However, at the five percent level, regular resignations also affect the exchange rate. Unanticipated resignations affect stock prices. Of all 41 exits in our exchange rate sample, 14 lead to significant market reactions, at least at the ten percent level of significance. 5 resignations affect bond spreads; 8 have a significant impact on stock markets.

Regarding the appointment of new governors, bond spreads and stock yields 
show - overall - significant reactions. The appointment of new governors with USbased education affects all three markets at the one percent level of significance. The appointment of an insider affects the exchange rate and bond spreads, while those of an outsider only affect stock market returns.

To summarize the broad picture, our results to some extent imply that rather irregular, unanticipated events than anticipated, regular events affect the markets. This implies that it is the change per se that matters for markets' reactions and not the reaction of markets to the resignation of governors with particular characteristics (as otherwise regular exits should also have clear effects on the markets). Overall, our hypotheses are supported by the data. Investors do react negatively to central bank governor changes. However, while this negative reaction suggests that market participants expect an increase in inflation after these irregular, unanticipated changes, the results are also in line with an alternative explanation. Arguably, market reactions might well reflect a general increase in risk perception following a change at the head of a central bank. However, our results show that stock markets react least to these changes. As stock markets are least likely to be affected by changes in expected inflation, but equally likely to be affected by perceived increases in risk more generally, we take this as evidence in favour of the importance of expectations about inflation. We return to this below.

Regarding the individual characteristics of incoming central bank governors, there is no systematic pattern among our various analyses. We also distinguished between dependent and independent central banks according to the definition in Arnone et al. (2007) but obtained no significant results.

Table 4 reports the results of the panel data analysis. As can be seen from column 1 , stock market returns decrease at the one percent level of significance with increasing market uncertainty, as measured by an increase in the volatility index (VIX) of the Chicago Board Options Exchange. Also at the one percent level, market returns rise with higher 10-year US Treasury bond yields. 3-month US Treasury bill yields, to the contrary, do not affect stock markets at conventional levels of significance. In column 2, we follow Kaminsky and Schmukler (2002) to address the potential bias 


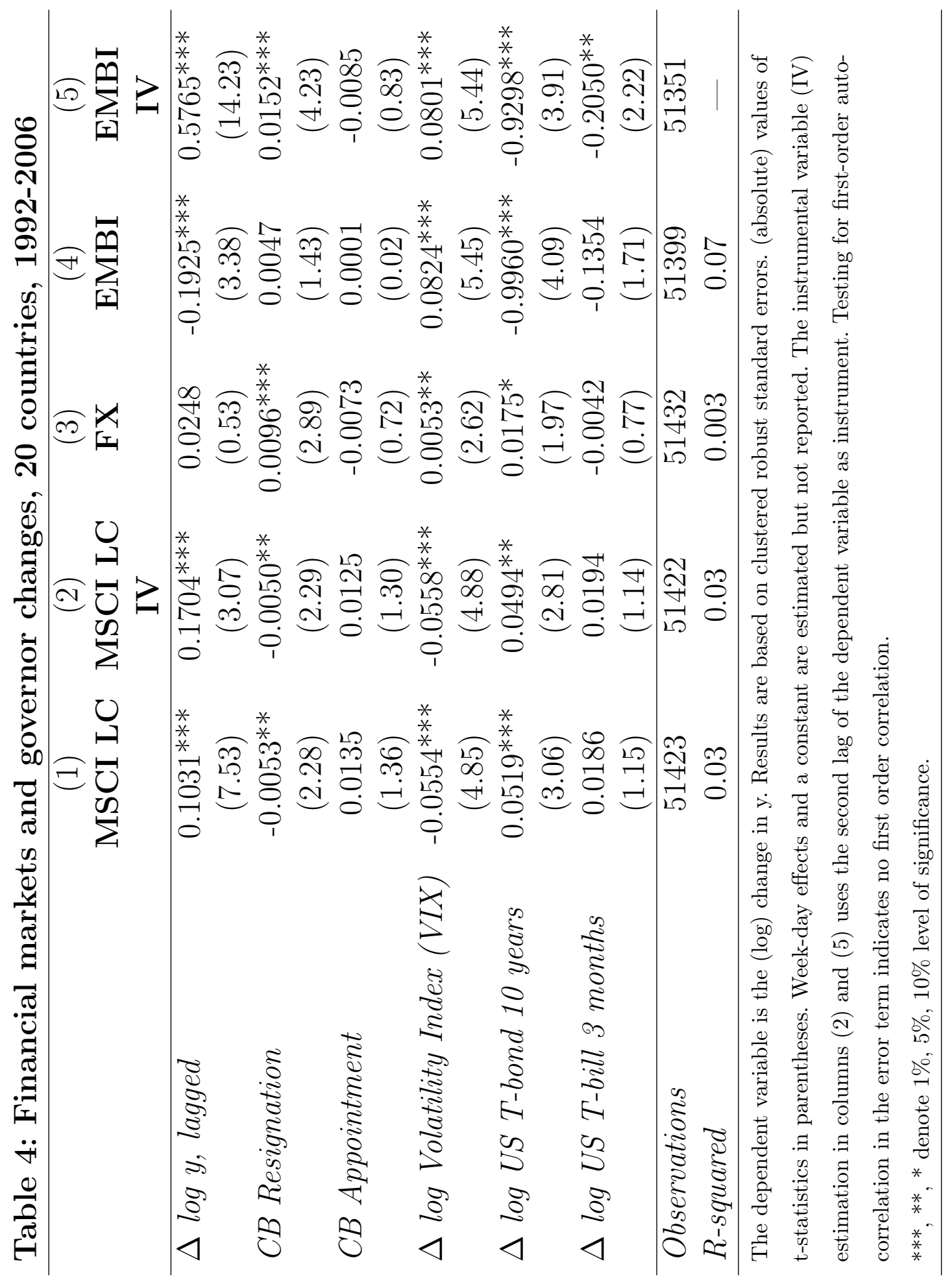


introduced by the correlation between the lagged dependent variable and the error term. We therefore instrument the (highly significant) lagged endogenous variable with its second lag (Anderson and Hsiao, 1982). Our results are not changed by this.

Column 3 shows the results for the exchange rate. The currency depreciates with greater volatility and increasing 10-year yields, while changes in 3-month yields again have no significant effect. The lagged dependent variable also is completely insignificant (and we therefore do not instrument it).

Results for bond spreads, finally, are reported in columns 4 and 5. Significant at the one percent level, spreads rise with higher volatility, and lower 10-year and 3-month yields. The lagged dependent variable is also significant at the one percent level according to the OLS specification of column 4 (with a negative coefficient), but is not significant at conventional levels once instrumented (column 5).

Turning to our variables of interest, Table 4 again shows that financial markets do react to the resignation of central bankers. They also show, however, that the appointment of a banker has no significant impact. Specifically, our results show that domestic stock markets react negatively to central bank turnovers. The estimated coefficients imply a small decline in returns of about 0.5 percent according to the IV regression, on average. ${ }^{23}$ Arguably, while far from being a dramatic crash of markets, this becomes economically important when we consider stock market returns in US dollar. Hence, for the international investor base - proxied by the US dollar denominated MSCI index - the combined decline in domestic stock and foreign exchange markets amounts to about 1.6 percent. ${ }^{24}$ Comparing these results to those of Kaminsky and Schmukler (2002) for the impact of changes in sovereign ratings, for example, shows that the magnitude of announcing a central bank governor change is about five times higher than those of announcing a change in sovereign ratings. Column 3 shows that the resignation of a central banker leads to a depreci-

\footnotetext{
${ }^{23}$ Note that these results are based on a sample excluding periods of fixed exchange rates and data without daily availability. While the omission does not qualitatively affect our results, the coefficient increases marginally.

${ }^{24}$ These point coefficients are based on an estimation, where the dependent variable is the MSCI stock market index denominated in US dollar.
} 
ation of the exchange rate, at the one percent level of significance. ${ }^{25}$ The estimated coefficient implies a depreciation of almost 1 percent following the resignation of a central banker. Columns 5 and 6, finally, show that bond spreads do not increase following the resignation of the head of the central bank according to the OLS regressions, but do increase (at the one percent level of significance) once taking the potential endogeneity of the lagged dependent variable into account. According to the coefficient, the resignation of a central bank governor increases bond spreads by more than 1.5 percent. To put the result on resignations into perspective, Kaminsky and Schmukler (2002) find an average effect of announcing a change in a country's sovereign rating on sovereign bond spreads that is about half of the effect we find for announcing the change of a central bank governor. Interestingly, the announcement effects triggered by changing the minister of finance and economics (Moser, 2006) are comparable to those resulting from changing the central bank governor. These findings support Santiso (2003), stating that policy makers in charge of the central bank, ministry of finance and economics are equally key in interacting with international financial markets.

Tables 5 to 7 investigate the issue in more detail. In Table 5, we distinguish regular from irregular resignations, by including the interaction of irregular turnovers with all turnovers. Table 6 seeks to control for changes in perceived conservatism and Table 7, finally, separates the sample according to the respective country's degree of central bank independence. Arguably, changes in central bank independence are more likely to be an issue in countries with low independence, while in countries with completely independent central banks personal characteristics are more likely to be important. Our definition of central bank independence follows Arnone et al. (2007), based on the method proposed in Grilli et al. (1991) and Cukierman (1992). These indices assess the political and economic independence of central banks based on legal criteria. We use the median of their average overall values over the late 1980-2003. As can be seen from Table 5, irregular turnovers lead to a depreciation of the exchange rate, while the exchange rate appreciates by a small

\footnotetext{
${ }^{25}$ Note that this result remains when the insignificant lagged dependent variable is omitted from the regressions.
} 


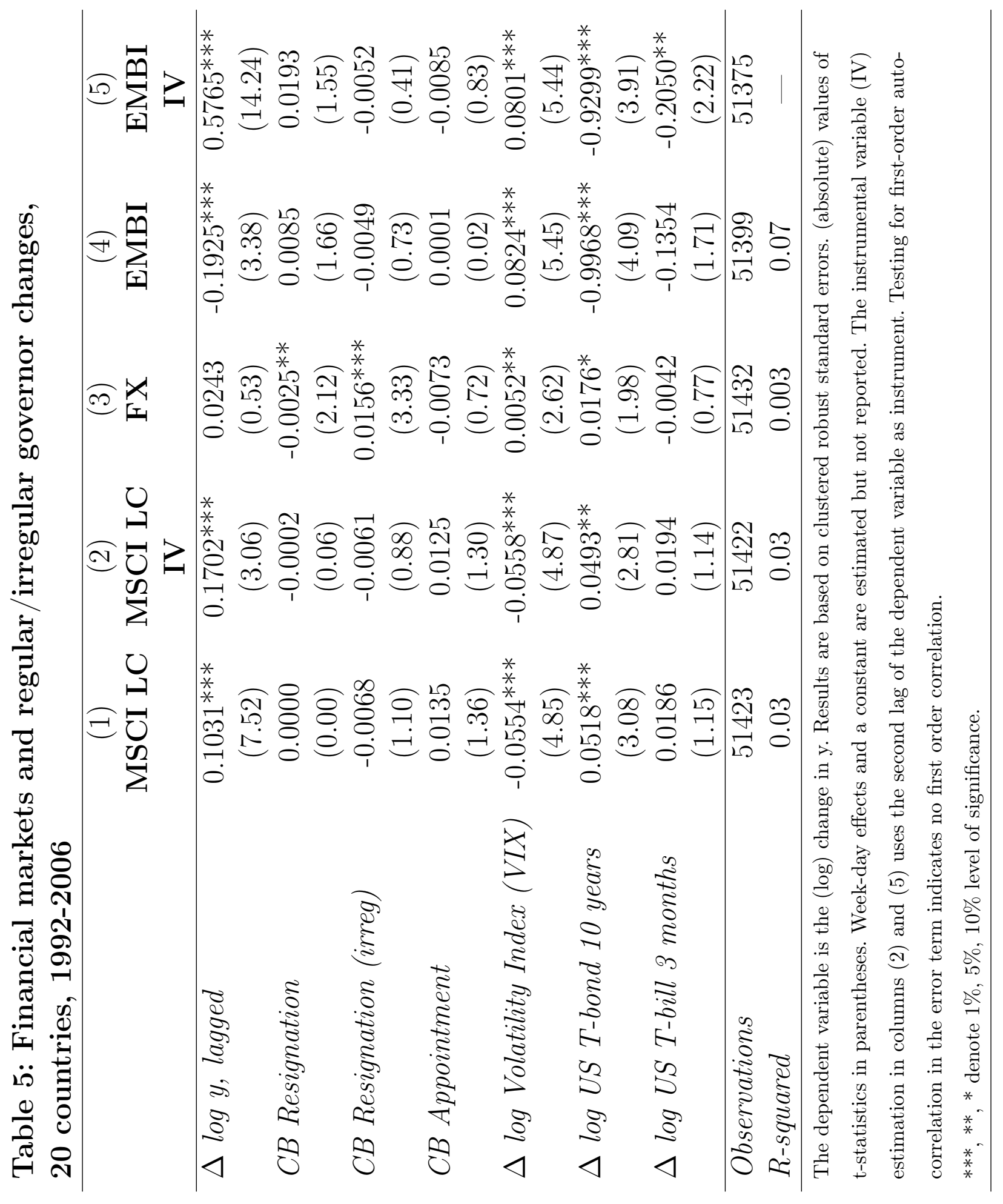


margin following regular turnovers (at the one and five percent level of significance, respectively). Assuming that personal characteristics of governors are on average the same across regular and irregular turnovers, the currency depreciation triggered by irregular events points to the importance of perceived central bank independence. More importantly, we do not find an announcement effect of resignations on the domestic stock or international bond market at conventional significance levels. If market reactions to irregular events were due to general market uncertainty rather than changing perceptions of central bank independence, we would expect such negative market reactions on all three markets. Instead, we find them exclusively for the inflation sensitive foreign exchange market. The results are thus more in line with the hypothesis that irregular resignations send a negative signal about central bank independence to foreign exchange market participants.

Table 6 tests for the impact of changes in the central bank governor's "conservativeness." We therefore included an interaction term between $\operatorname{RESIGN_{i,t}} * \operatorname{IRREG_{i,t}}$ and a dummy variable that takes the value one when the nominating government's partisanship has changed from the previous one (PARTISAN $\left.N_{i, t}\right)$. Clearly, if our hypothesis that perceived central bank independence matters is correct, we will expect that our $\beta_{2}$-coefficient - proxying for perceived central bank independence remains significant once we explicitly control for the second dimension of the inflationary bias, namely changes in conservatism. While our results indeed confirm that investors are worried about central bank independence, the additional interaction term does not turn out significant. Hence, we do not find an independent effect for conservatism in the case of irregular resignations. All other results shown in Table 5 remain.

In Table 7 we separate the samples according to independent and dependent central banks (omitting the OLS regressions for the bond and stock markets). ${ }^{26}$ As can be seen, the results do not substantially differ across the two samples. Irregular resignations of the central bank governor go along with a depreciation of the exchange rate, while there is no significant impact on stock and bond markets. The effect of

\footnotetext{
${ }^{26}$ Note that the results regarding our variables of interest are the same when estimated with OLS
} 


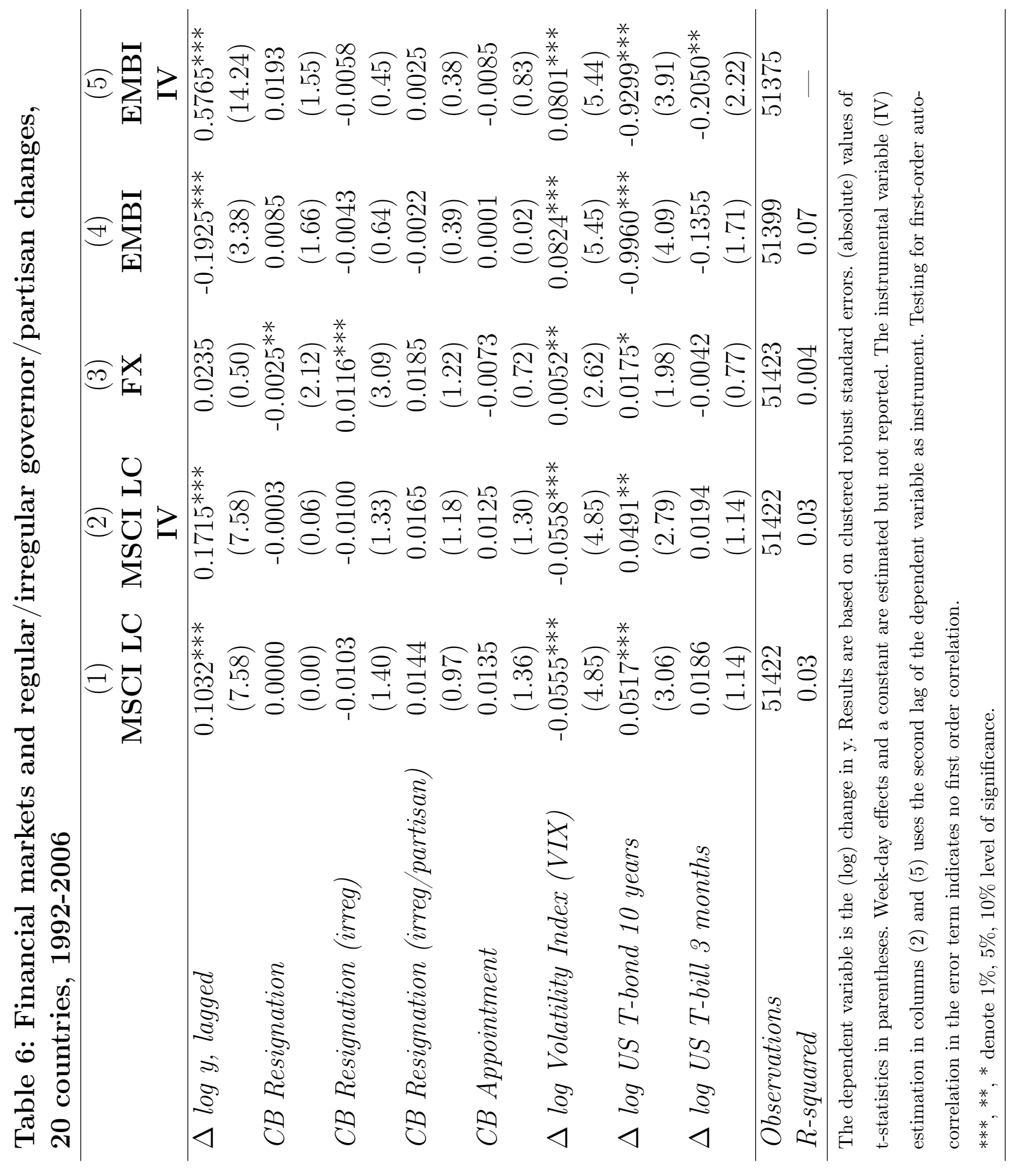




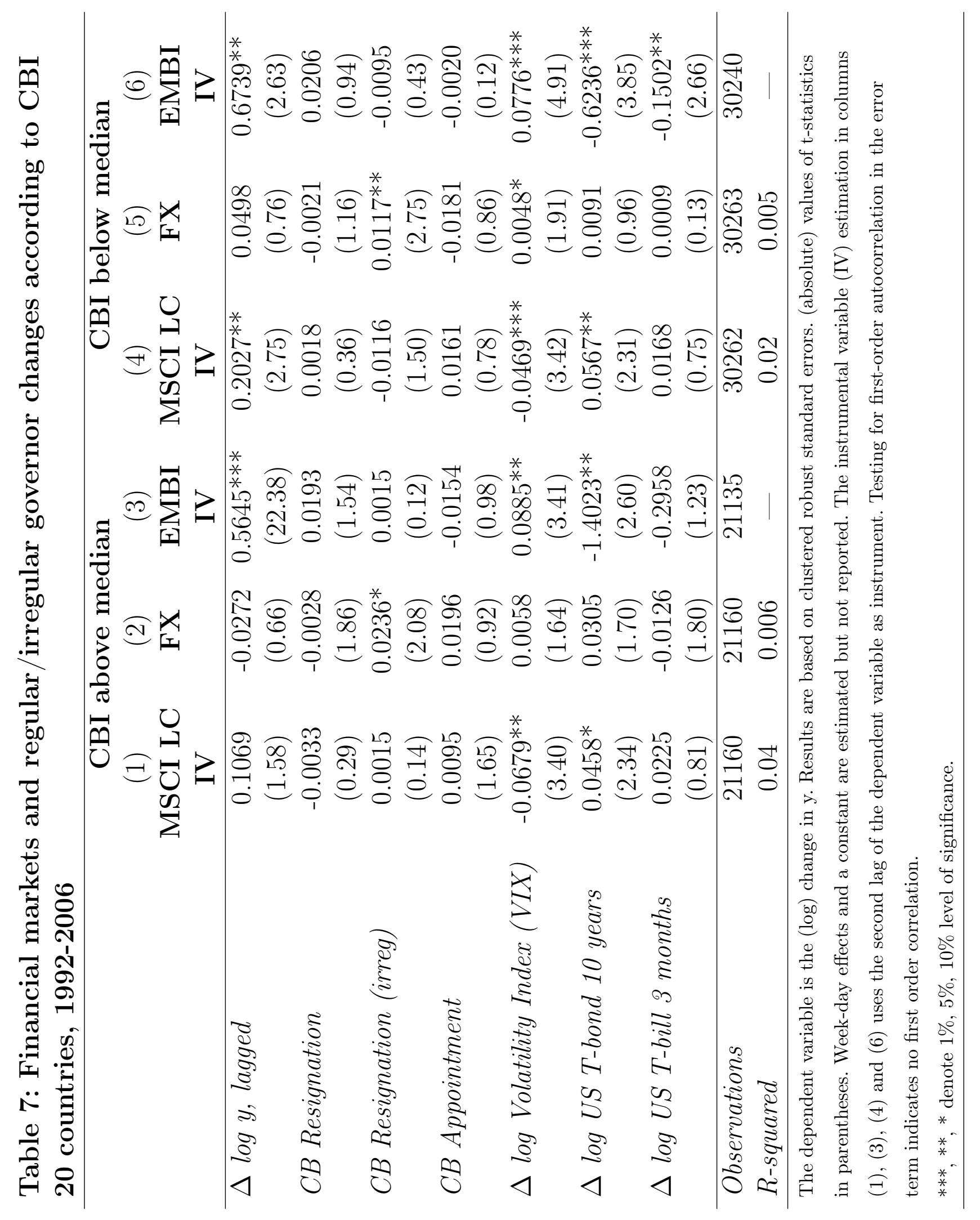


resignations on exchange rates is quantitatively more pronounced in countries with greater central bank independence. In these countries, an irregular resignation leads to a depreciation of more than two percent, almost twice as high as the corresponding depreciation in countries with below median central bank independence. This is intuitive. If the central bank depends on politics in the first place, irregular resignations are less likely to change market perceptions about its independence. With banks that show some degree of independence, irregular changes are more likely to affect perceptions. We take this as additional evidence in favor of our argument that personal characteristics of the central banker are less important than changes in perceived independence.

Table 8 separately investigates anticipated and unanticipated resignations, while Table 9 focuses on the appointment of insiders/outsiders and governors with/without

Table 8: Financial markets and (un)anticipated governor changes, 20 countries, 1992-2006

\begin{tabular}{lccc}
\hline & $(1)$ & $(2)$ & $(3)$ \\
& MSCI LC & FX & EMBI \\
& IV & & IV \\
\hline$\Delta$ log y, lagged & $0.170^{* * *}$ & 0.024 & $0.576^{* * *}$ \\
& $(3.07)$ & $(0.53)$ & $(14.25)$ \\
CB Resignation & $-0.005^{* *}$ & $0.013^{* * *}$ & $0.012^{* * *}$ \\
& $(2.51)$ & $(3.23)$ & $(4.08)$ \\
CB Resignation (anticipated) & 0.003 & $-0.018^{* * *}$ & 0.018 \\
& $(0.35)$ & $(3.49)$ & $(1.22)$ \\
CB Appointment & 0.013 & -0.007 & -0.009 \\
& $(1.30)$ & $(0.72)$ & $(0.83)$ \\
$\Delta$ log Volatility Index (VIX) & $-0.056^{* * *}$ & $0.005^{* *}$ & $0.080^{* * *}$ \\
& $(4.88)$ & $(2.62)$ & $(5.44)$ \\
$\Delta$ log US T-bond 10 years & $0.049^{* *}$ & $0.018^{*}$ & $-0.930^{* * *}$ \\
& $(2.81)$ & $(1.98)$ & $(3.92)$ \\
$\Delta$ log US T-bill 3 months & 0.020 & -0.004 & $-0.205^{* *}$ \\
& $(1.14)$ & $(0.78)$ & $(2.22)$ \\
\hline Observations & 51422 & 51423 & 51375 \\
R-squared & 0.03 & 0.004 & - \\
\hline The dependent variable is the (log) change in y. Results are based on clustered \\
robust standard errors. Figures in parentheses are t-values. Week-day effects and \\
a constant are estimated but not reported. The instrumental variable (IV) estimation \\
in columns (1) and (3) uses a second lag of the dependent variable as an instrument. \\
Testing for first-order autocorrelation in the error term via "areg" indicates no \\
first order correlation. \\
***,**, * denote 1\%, 5\%, 10\% level of significance. & & \\
\hline
\end{tabular}


US based education. Due to the small number of observations involved in some cases, the results have to be interpreted with caution. According to Table 8, anticipated governor changes reduce the impact of changes on the exchange rate. In fact, the appreciation caused by anticipated changes slightly exceeds the depreciation following the change in general. In line with the results reported above, the impact of anticipated resignations is small, but significant. As argued above, this effect might arise from a perceived change in conservatism, as half of the anticipated events also involve a change in the partisanship of the nominating government. Overall, the results again show that it is the unanticipated changes driving the negative result on the exchange rate.

Turning to individual characteristics of central bank governors, Table 9 shows that none of the additional interaction terms are significant at conventional levels. We conclude that personal characteristics of central bank governors do not matter for market reactions.

In summary, our results show that financial markets do react to central bank governor changes. This negative effect is mainly driven by irregular, unanticipated events. Market participants are sensitive to signals about perceived central bank independence, expecting higher inflationary bias. This claim holds particularly true for the foreign exchange market, which is the market most prone to inflation concerns in our study. On the other hand, it does not come as a surprise that the overall picture for investors in domestic stock and international bond markets is more mixed, since these markets are (at most) indirectly affected by inflation expectations. Still, these market participants may demand higher risk premia due to negative policy signals from the incumbent government. The governor's degree of conservatism, to the contrary, does not seem to matter for market reactions, and the same is true for personal characteristics of the central banker. 


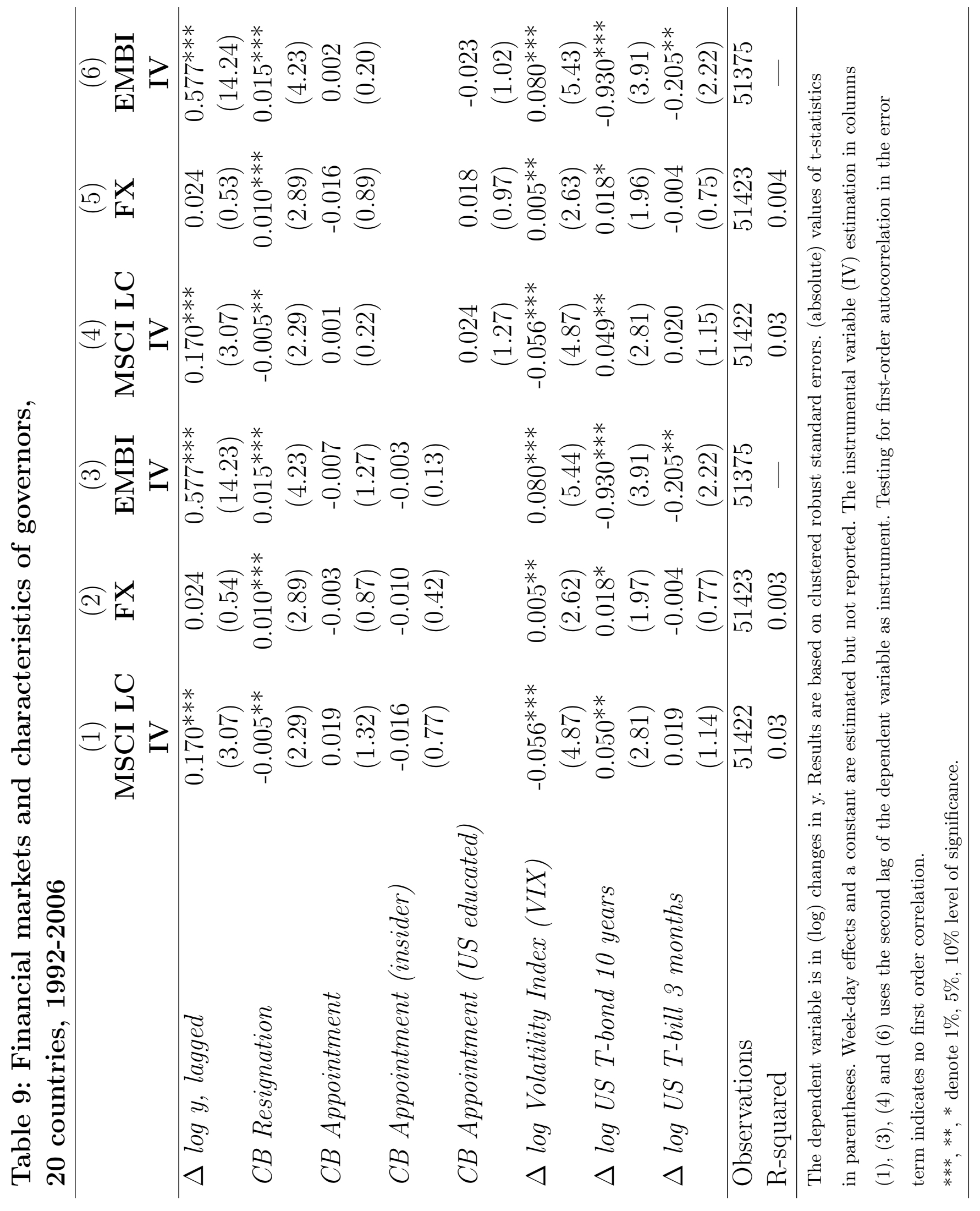




\section{Conclusion}

Central bank governor changes in emerging markets may convey important signals about future monetary policy. Based on a new daily data set, this paper has examined the reactions of foreign exchange markets, domestic stock market indices and sovereign bond spreads to the announcement of a central bank governor change. The sample comprises all emerging markets with reliable data for all three financial market indicators, covering 20 emerging economies over the period 1992-2006.

Our results show, first, that the resignation of a central bank governor negatively affects financial markets on the announcement day, with average market reactions between 0.5 to 1.5 percent. While these effects are economically relevant and relatively large in comparison to announcement effects known from changes in sovereign risk ratings, we find less evidence that appointments of new governors incorporate relevant news for investors. Second, comparing our results to the previous literature, we find that our results for emerging market economies are distinct from industrialized countries in an interesting aspect. Newly appointed central bank governors apparently suffer from a systematic credibility problem at the beginning of their tenure. In contrast to their counterparts in industrialized countries, emerging market governors initially have to face (at least) a transitory rise in inflation expectations because investors are uncertain about the true type of the central bank governor ("hawkish" vs. "dovish"). Third, the negative announcement effect for resignations is mainly driven by irregular changes, i.e. changes occurring before the scheduled end of tenure. We offer two interpretations. First, foreign exchange market participants are apparently sensitive to signals about perceived central bank independence, expecting higher inflationary bias. This also holds true, when we explicitly control for perceived changes in conservatism. Second, more generally, investors in domestic stock and international bond markets may simply demand higher risk premia due to negative policy signals from the incumbent government. ${ }^{27}$ As we find negative announcement effects exclusively for the inflation sensitive foreign exchange market, however, our results are more in line with the hypothesis that irregular resignations

\footnotetext{
${ }^{27}$ Turnovers might e.g. signal problems that were not recognized before.
} 
send a negative signal about central bank independence to foreign exchange market participants. The governor's degree of conservatism does not seem to matter for market reactions. Finally, there is little evidence that personal characteristics of the central banker matter for market reactions.

Overall, our study complements the view of Santiso (2003) that key policy makers in emerging markets are crucial for building credibility in international financial markets in one important aspect. Investors are apparently sensitive to the way an incumbent government handles the replacement of key policy makers. With respect to central bank governor changes, investors seem to care most about perceived central bank independence. As this study focused on announcement effects, we do not know whether and to what extent such news affect the markets beyond the announcement day. We leave this question for future research. 


\section{References}

Adolph, C. A. (2004). The Dilemma of Discretion: Career Ambitions and the Politics of Central Banking. PhD Thesis, Harvard University.

Anderson, T. and C. Hsiao (1982). Formulation and Estimation of Dynamic Models Using Panel Data. Journal of Econometrics 18, 47-82.

Andritzky, J., G. Bannister and N. Tamirisa (2007). The Impact of Macroeconomic Announcements on Emerging Market Bonds. Emerging Markets Review 8, 20-37.

Arnone, M., B.J. Laurens, J.-F. Segalotto and M. Sommer (2007). Central Bank Autonomy: Lessons from Global Trends. IMF Working Paper No. 07/88.

Backus, D. and J. Driffill (1985). Inflation and Reputation. American Economic Review 75, 530-538.

Barro, R. (1986). Reputation in a Model of Monetary Policy with Incomplete Information. Journal of Monetary Economics 17, 3-20.

Barro, R. and D. Gordon (1983). A Positive Theory of Monetary Policy in a Naturalrate Model. Journal of Political Economy 91, 598-610.

Beck, T., G. Clarke, A. Groff, P. Keefer and P. Walsh (2001). New Tools in Comparative Political Economy: The Database of Political Institutions. World Bank Economic Review 17, 165-176.

Berger, H. and U. Woitek (2005). Does Conservatism Matter? A Time-series Approach to Central Bank Behaviour. The Economic Journal 115, 745-766.

Berger, H., J. de Haan and S. Eijffinger (2001). Central Bank Independence: An Update of Theory and Evidence. Journal of Economic Surveys 15, 3-40.

Besley, T., R. Pande and V. Rao (2005). Political Selection and the Quality of Government: Evidence from South India. CEPR Discussion Paper No. 5201.

Caballero, R. and A. Krishnamurthy (2004). Fiscal Policy and Financial Depth. NBER Working Paper No. 10532.

Cukierman, A. (1992). Central Bank Strategy, Credibility, and Autonomy. MIT Press.

Cukierman, A. and A. Meltzer (1986). A Theory of Ambiguity, Credibility, and Inflation under Discretion and Asymmetric Information. Econometrica 54, 10991128.

Dreher, A., M. Lamla, S. Rupprecht and F. Somogyi (2006). The Impact of Political Leaders Profession and Education on Reforms. KOF Working Paper No. 147.

Duecker, M. (1999). Barometer of Financial Market Uncertainty, Monetary Trends. The Federal Reserve Bank of St. Louis.

Eijffinger, S. and M. Hoeberichts (1998). The Trade off between Central Bank Independence and Conservativeness. Oxford Economic Papers 50, 397-411. 
Fama, E. (1981). Stock Returns, Real Activity, Inflation and Money. American Economic Review 71, 545-565.

Göhlmann, S. and R. Vaubel (2007). The Educational and Professional Background of Central Bankers and its Effect on Inflation: An Empirical Analysis. European Economic Review 51, 925-941.

Grilli, V., D. Masciandaro and G. Tabellini (1991). Political and Monetary Institutions and Public Financial Policies in the Industrial Countries. Economic Policy 13, 341-92.

Gürkaynak, R., B. Sack and E. Swanson (2005). The Sensitivity of Long-term Interest Rates to Economics News: Evidence and Implications for Macroeconomic Models. American Economic Review 95, 425-436.

IMF (2001). International Capital Markets: Developments, Prospects and Key Policy Issues.

Jones, B. and B. Olken (2005). Do Leaders Matter? National Leadership and Growth since World War II. Quarterly Journal of Economics 120, 835-864.

Kaminsky, G. and S. Schmukler (2002). Emerging Markets Instability: Do Sovereign Ratings Affect Country Risk and Stock Returns. World Bank Economic Review 16, 171-195.

Kara, H. (2007). Monetary Policy under Imperfect Commitment: Reconciling Theory with Evidence. International Journal of Central Banking 3, 149-177.

Kuttner, K. and A. Posen (2007). Do Markets Care Who Chairs the Central Bank? Peterson Institute for International Economics Working Paper No. 07-03.

Kydland, F. and E. Prescott (1977). Rules Rather Than Discretion: The Inconsistency of Optimal Plans. Journal of Political Economy 85, 473-490.

McCallum, B. (1995). Two Fallacies Concerning Central-bank Independence. American Economic Review, Papers and Proceedings 85, 207-211.

Moser, C. (2006). The Impact of Political Risk on Sovereign Bond Spreads: Evidence from Latin America. University of Mainz, mimeo.

New York Times, T. (2001). Chief of Thai Bank is Dismissed Over Rates, May 30, 2001. Source: Proquest.

Obstfeld, M. and K. Rogoff (1996). Foundations of International Macroeconomics. MIT Press.

Pantzalis, C., D. Stangeland and Harry Turtle (2000). Political Elections and the Resolution of Uncertainty: The International Evidence. Journal of Banking and Finance 24, 1575-1604.

Peter, M. (2005). Direct Sovereign Risk, Indirect Sovereign Risk and Currency Risk: Three Essays on the Determinants of Investment Risks in Emerging Markets.

Piga, G. (2000). Dependent and Accountable: Evidence from the Modern Theory of Central Banking,. Journal of Economic Surveys 14, 563-569. 
Rogoff, K. (1985). The Optimal Degree of Commitment to an Intermediate Monetary Target. Quarterly Journal of Economics 100.

Santiso, J. (2003). The Political Economy of Emerging Markets. Actors, Institutions and Financial Crises in Latin America. CERI Series in International Relations and Political Economy, Palgrave Macmillan.

Schaumburg, E. and A. Tambalotti (2007). An Investigation of the Gains from Commitment in Monetary Policy. Journal of Monetary Economics 54, 302-324.

Schwert, W. (1981). The Adjustment of Stock Prices to Information about Inflation. Journal of Finance 36, 15-29. 


\section{A Appendix}

Appendix 1: Number of central bank governor changes by country

Number of central bank governor changes by country

Country Number events Country Number events

\begin{tabular}{llll}
\hline Argentina & $6(3)$ & Pakistan & $1(1)$ \\
Brazil & $9(2)$ & Peru & $4(3)$ \\
Chile & $1(1)$ & Philippines & $2(1)$ \\
China & $1(0)$ & Poland & $1(2)$ \\
Colombia & $1(0)$ & Russia & $2(1)$ \\
Egypt & $2(1)$ & South Africa & $0(1)$ \\
Hungary & $1(1)$ & South Korea & $2(0)$ \\
Malaysia & $2(1)$ & Thailand & $2(0)$ \\
Mexico & $1(0)$ & Turkey & $2(2)$ \\
Morocco & $1(0)$ & Venezuela & $3(1)$ \\
\hline
\end{tabular}

Note: This table reports the number of central bank governor resignations

(appointments) over the period 1992-2006.

Appendix 2: Data availability EMBI(G), FX to US Dollar and MSCI available

\begin{tabular}{cccccc}
\hline Country & Start & End Country & Start & End \\
\hline Argentina & 30.04 .1993 & 31.07 .2006 & Pakistan & 29.06 .2001 & 10.08 .2006 \\
Brazil & 15.01 .1992 & 01.08 .2006 & Peru & 30.05 .1997 & 11.08 .2006 \\
Chile & 28.05 .1999 & 02.08 .2006 & Philippines & 31.12 .1991 & 12.08 .2006 \\
China & 31.12 .1997 & 03.08 .2006 & Poland & 31.12 .1997 & 13.08 .2006 \\
Colombia & 31.12 .1997 & 04.08 .2006 & Russia & 31.12 .1997 & 14.08 .2006 \\
Egypt & 31.07 .2001 & 05.08 .2006 & South Africa & 31.12 .1997 & 15.08 .2006 \\
Hungary & 29.01 .1999 & 06.08 .2006 & South Korea & 31.12 .1997 & 16.08 .2006 \\
Malaysia & 31.12 .1997 & 07.08 .2006 & Thailand & 31.12 .1997 & 17.08 .2006 \\
Mexico & 31.12 .1991 & 08.08 .2006 & Turkey & 31.12 .1997 & 18.08 .2006 \\
Morocco & 31.12 .1997 & 09.08 .2006 & Venezuela & 31.12 .1992 & 19.08 .2006 \\
\hline
\end{tabular}

Appendix 3: Descriptive statistics

\begin{tabular}{lcccc}
\hline Variable & Mean & Std. Dev. & Min & Max \\
\hline$(\log )$ spread & 5.68 & 1.07 & 0.00 & 8.88 \\
$(\log )$ MSCI & 5.53 & 1.06 & 2.55 & 8.61 \\
(log) exchange rate & 3.09 & -2.44 & 7.82 & 8.00 \\
Central banker change & 0.00 & 0.03 & 0.00 & 1.00 \\
(log) VIX & 2.91 & 0.32 & 2.23 & 3.90 \\
$(\log )$ US T-bond 10 years & 1.94 & 0.22 & 1.41 & 2.35 \\
$(\log )$ US T-bill 3 months & 1.62 & 0.42 & 0.59 & 2.31 \\
\hline
\end{tabular}




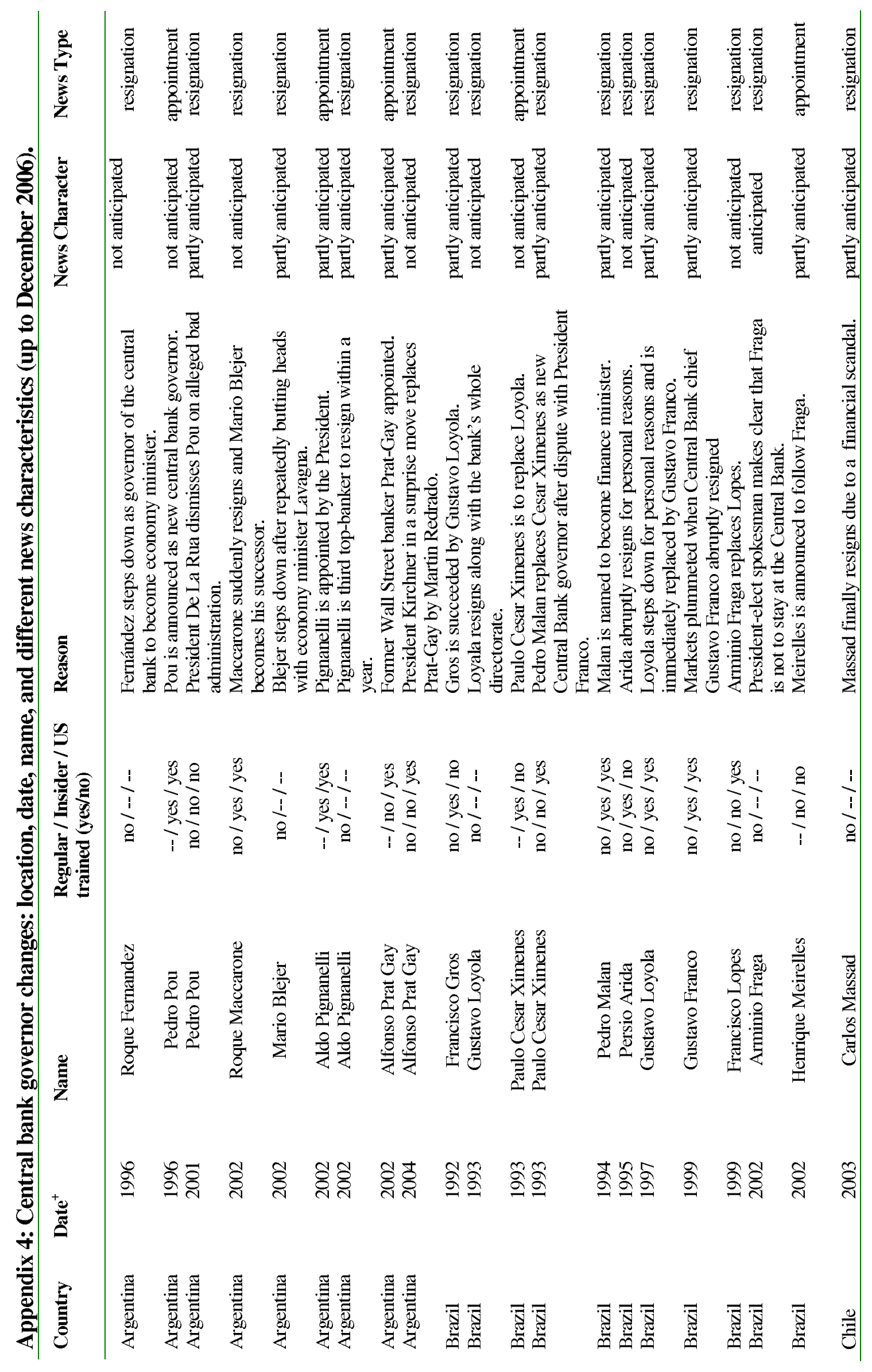

Figure 2: Central Bank Governor Changes 


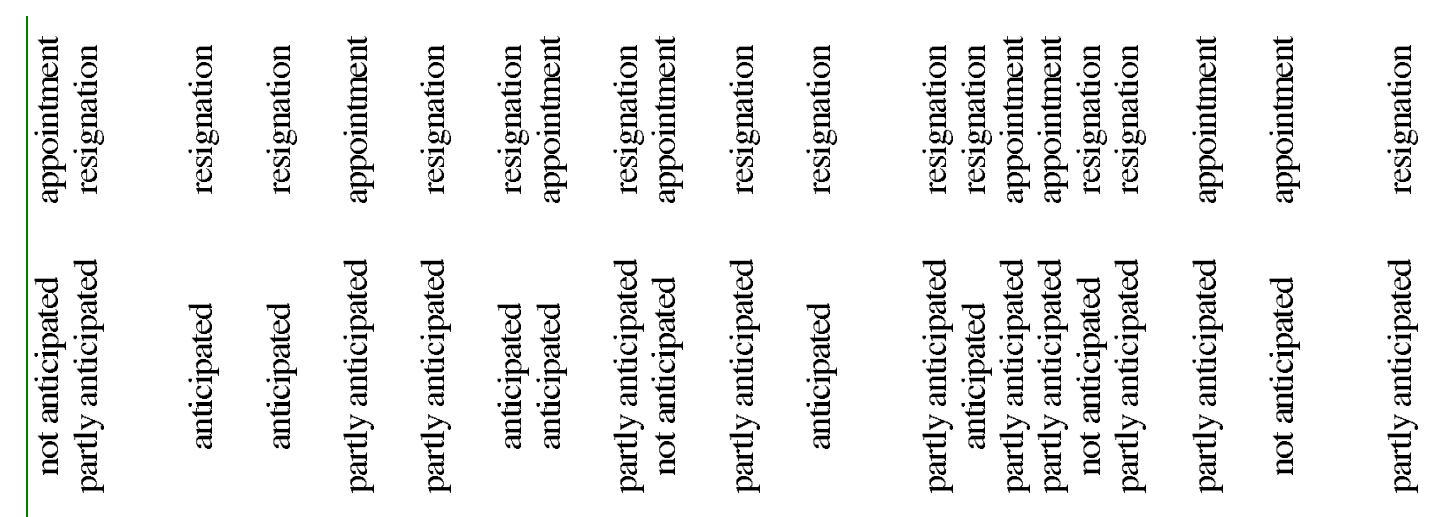

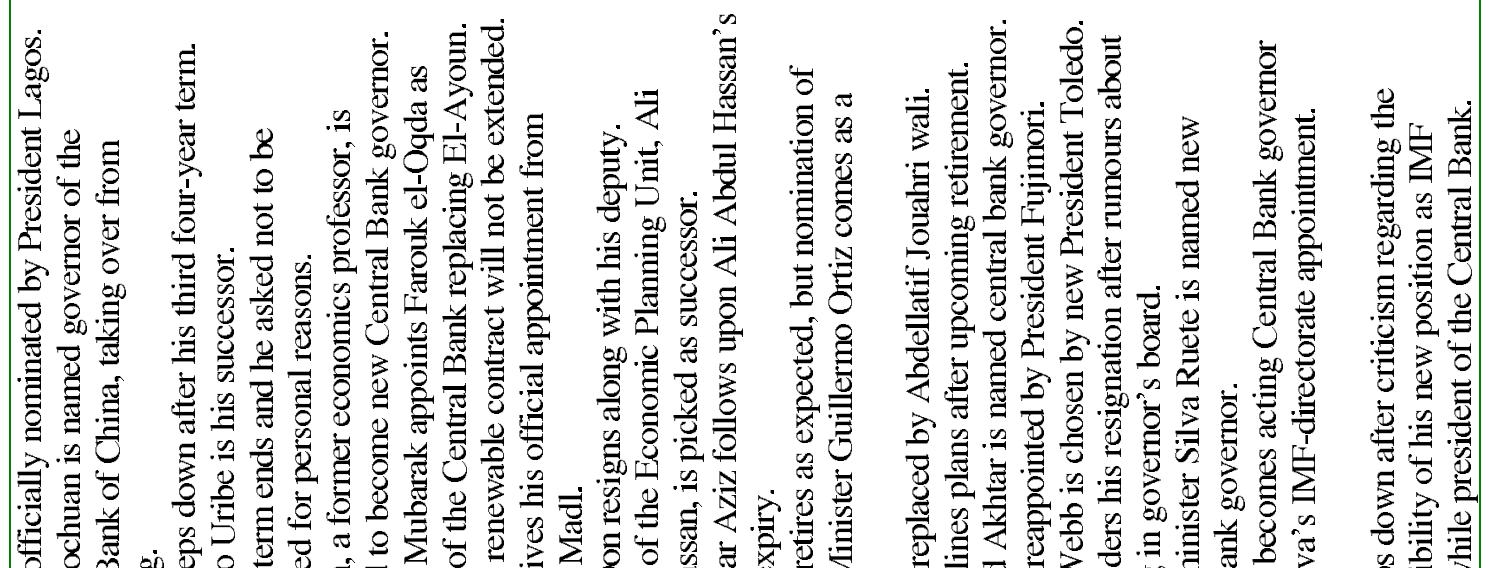
Whand

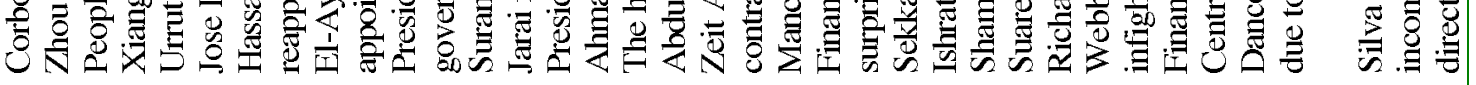

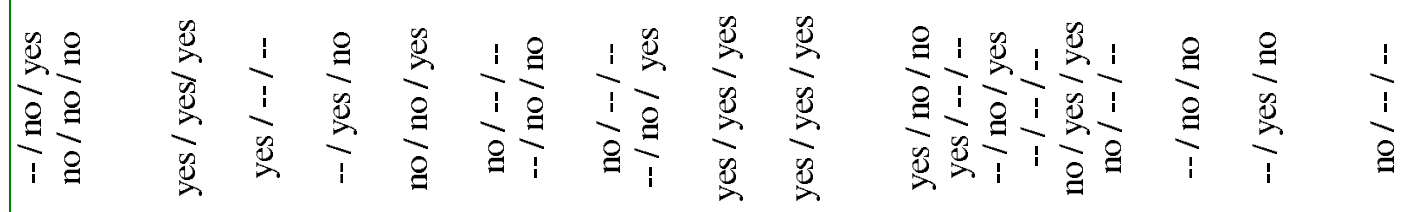

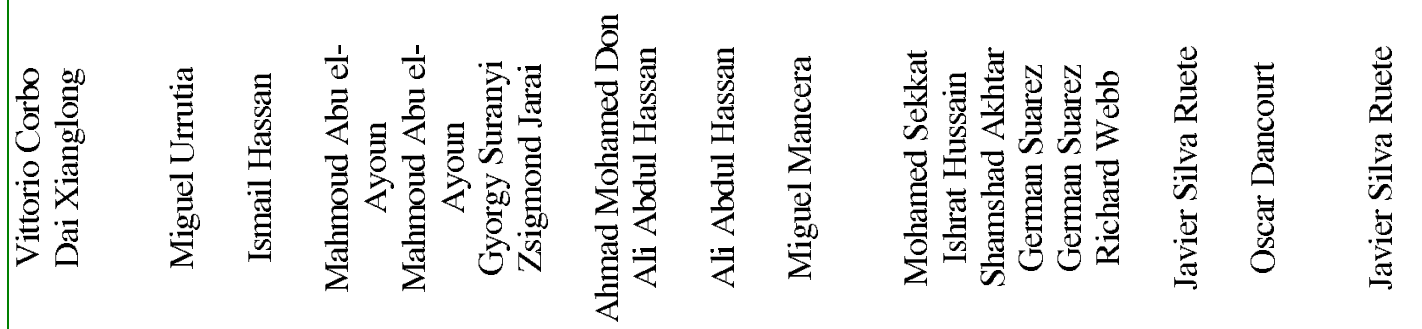

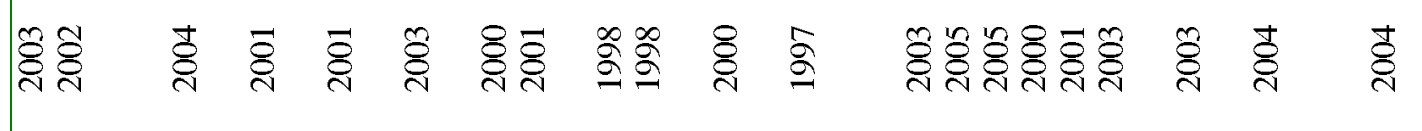

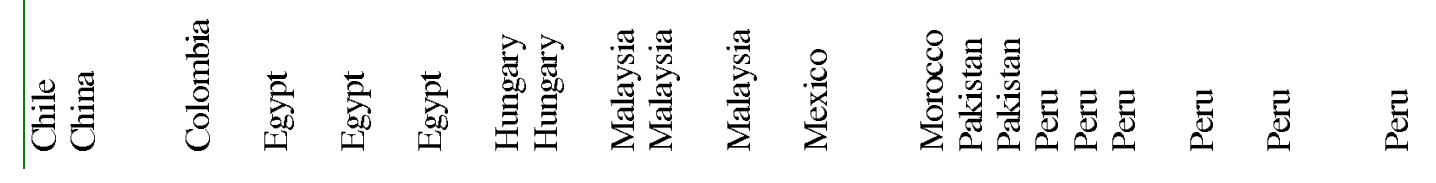




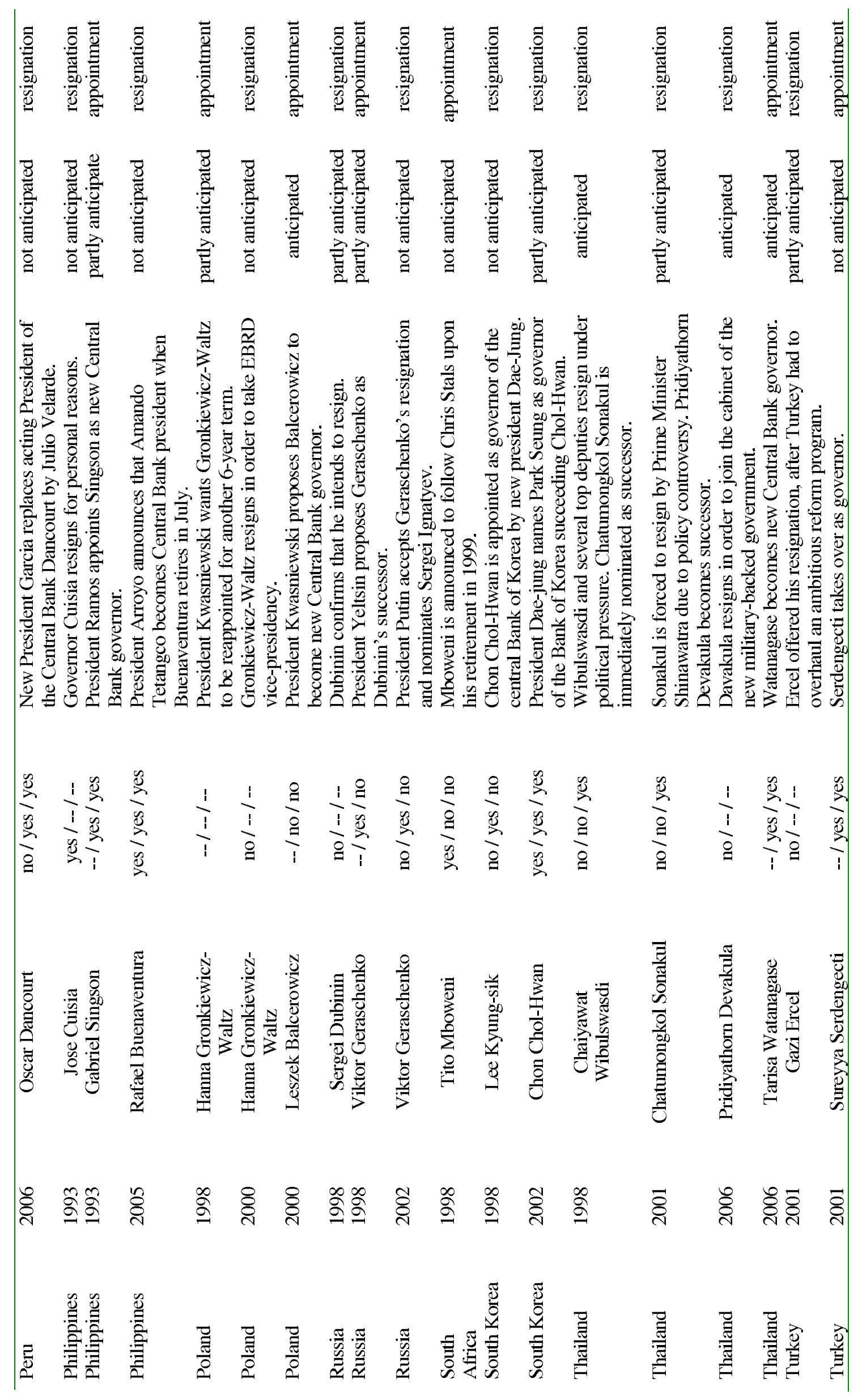




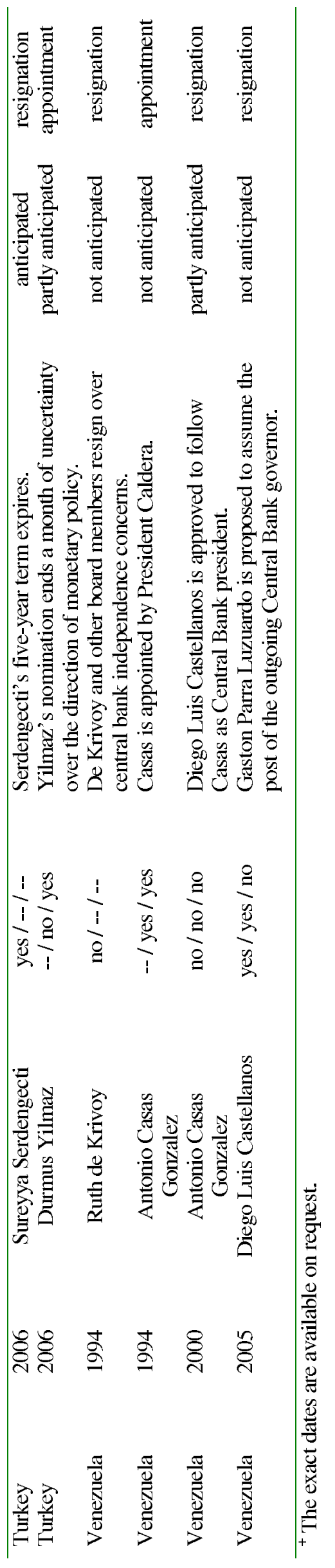




\section{CESifo Working Paper Series}

for full list see www.cesifo-group.org/wp

(address: Poschingerstr. 5, 81679 Munich, Germany, office@cesifo.de)

2112 Mark Mink, Jan P.A.M. Jacobs and Jakob de Haan, Measuring Synchronicity and Comovement of Business Cycles with an Application to the Euro Area, October 2007

2113 Ossip Hühnerbein and Tobias Seidel, Intra-regional Tax Competition and Economic Geography, October 2007

2114 Christian Keuschnigg, Exports, Foreign Direct Investment and the Costs of Corporate Taxation, October 2007

2115 Werner Bönte, Oliver Falck and Stephan Heblich, Demography and Innovative Entrepreneurship, October 2007

2116 Katrin Assenmacher-Wesche and M. Hashem Pesaran, Assessing Forecast Uncertainties in a VECX Model for Switzerland: An Exercise in Forecast Combination across Models and Observation Windows, October 2007

2117 Ben Lockwood, Voting, Lobbying, and the Decentralization Theorem, October 2007

2118 Andrea Ichino, Guido Schwerdt, Rudolf Winter-Ebmer and Josef Zweimüller, Too Old to Work, too Young to Retire?, October 2007

2119 Wolfgang Eggert, Tim Krieger and Volker Meier, Education, Unemployment and Migration, October 2007

2120 Stefan Napel and Mika Widgrén, The European Commission - Appointment, Preferences, and Institutional Relations, October 2007

2121 Bertil Holmlund and Martin Söderström, Estimating Income Responses to Tax Changes: A Dynamic Panel Data Approach, October 2007

2122 Doina Maria Radulescu, From Separate Accounting to Formula Apportionment: Analysis in a Dynamic Framework, October 2007

2123 Jelle Brouwer, Richard Paap and Jean-Marie Viaene, The Trade and FDI Effects of EMU Enlargement, October 2007

2124 Kurt R. Brekke, Luigi Siciliani and Odd Rune Straume, Competition and Waiting Times in Hospital Markets, October 2007

2125 Alexis Direr, Flexible Life Annuities, October 2007

2126 Johannes Becker and Clemens Fuest, Quality versus Quantity - The Composition Effect of Corporate Taxation on Foreign Direct Investment, October 2007 
2127 Balázs Égert, Real Convergence, Price Level Convergence and Inflation Differentials in Europe, October 2007

2128 Marko Koethenbuerger, Revisiting the "Decentralization Theorem” - On the Role of Externalities, October 2007

2129 Axel Dreher, Silvia Marchesi and James Raymond Vreeland, The Politics of IMF Forecasts, October 2007

2130 Andreas Knabe and Ronnie Schöb, Subsidizing Extra Jobs: Promoting Employment by Taming the Unions, October 2007

2131 Michel Beine and Bertrand Candelon, Liberalization and Stock Market Co-Movement between Emerging Economies, October 2007

2132 Dieter M. Urban, FDI Technology Spillovers and Wages, October 2007

2133 Valentina Bosetti, Carlo Carraro, Emanuele Massetti and Massimo Tavoni, Optimal Energy Investment and R\&D Strategies to Stabilise Greenhouse Gas Atmospheric Concentrations, October 2007

2134 David-Jan Jansen and Jakob de Haan, The Importance of Being Vigilant: Has ECB Communication Influenced Euro Area Inflation Expectations?, October 2007

2135 Oliver Falck, Heavyweights - The Impact of Large Businesses on Productivity Growth, October 2007

2136 Xavier Freixas and Bruno M. Parigi, Banking Regulation and Prompt Corrective Action, November 2007

2137 Jan K. Brueckner, Partial Fiscal Decentralization, November 2007

2138 Silvia Console Battilana, Uncovered Power: External Agenda Setting, Sophisticated Voting, and Transnational Lobbying, November 2007

2139 Alan J. Auerbach, Michael P. Devereux and Helen Simpson, Taxing Corporate Income, November 2007

2140 Lorenzo Cappellari, Paolo Ghinetti and Gilberto Turati, On Time and Money Donations, November 2007

2141 Roel Beetsma and Heikki Oksanen, Pension Systems, Ageing and the Stability and Growth Pact, November 2007

2142 Hikaru Ogawa and David E. Wildasin, Think Locally, Act Locally: Spillovers, Spillbacks, and Efficient Decentralized Policymaking, November 2007

2143 Alessandro Cigno, A Theoretical Analysis of the Effects of Legislation on Marriage, Fertility, Domestic Division of Labour, and the Education of Children, November 2007 
2144 Kai A. Konrad, Mobile Tax Base as a Global Common, November 2007

2145 Ola Kvaløy and Trond E. Olsen, The Rise of Individual Performance Pay, November 2007

2146 Guglielmo Maria Caporale, Yannis Georgellis, Nicholas Tsitsianis and Ya Ping Yin, Income and Happiness across Europe: Do Reference Values Matter?, November 2007

2147 Dan Anderberg, Tax Credits, Income Support and Partnership Decisions, November 2007

2148 Andreas Irmen and Rainer Klump, Factor Substitution, Income Distribution, and Growth in a Generalized Neoclassical Model, November 2007

2149 Lorenz Blume, Jens Müller and Stefan Voigt, The Economic Effects of Direct Democracy - A First Global Assessment, November 2007

2150 Axel Dreher, Pierre-Guillaume Méon and Friedrich Schneider, The Devil is in the Shadow - Do Institutions Affect Income and Productivity or only Official Income and Official Productivity?, November 2007

2151 Valentina Bosetti, Carlo Carraro, Emanuele Massetti and Massimo Tavoni, International Energy R\&D Spillovers and the Economics of Greenhouse Gas Atmospheric Stabilization, November 2007

2152 Balázs Égert and Dubravko Mihaljek, Determinants of House Prices in Central and Eastern Europe, November 2007

2153 Christa Hainz and Hendrik Hakenes, The Politician and his Banker, November 2007

2154 Josef Falkinger, Distribution and Use of Knowledge under the "Laws of the Web", December 2007

2155 Thorvaldur Gylfason and Eduard Hochreiter, Growing Apart? A Tale of Two Republics: Estonia and Georgia, December 2007

2156 Morris A. Davis and François Ortalo-Magné, Household Expenditures, Wages, Rents, December 2007

2157 Andreas Haufler and Christian Schulte, Merger Policy and Tax Competition, December 2007

2158 Marko Köthenbürger and Panu Poutvaara, Rent Taxation and its Intertemporal Welfare Effects in a Small Open Economy, December 2007

2159 Betsey Stevenson, Title IX and the Evolution of High School Sports, December 2007

2160 Stergios Skaperdas and Samarth Vaidya, Persuasion as a Contest, December 2007 
2161 Morten Bennedsen and Christian Schultz, Arm’s Length Provision of Public Services, December 2007

2162 Bas Jacobs, Optimal Redistributive Tax and Education Policies in General Equilibrium, December 2007

2163 Christian Jaag, Christian Keuschnigg and Mirela Keuschnigg, Pension Reform, Retirement and Life-Cycle Unemployment, December 2007

2164 Dieter M. Urban, Terms of Trade, Catch-up, and Home Market Effect: The Example of Japan, December 2007

2165 Marcelo Resende and Rodrigo M. Zeidan, Lionel Robbins: A Methodological Reappraisal, December 2007

2166 Samuel Bentolila, Juan J. Dolado and Juan F. Jimeno, Does Immigration Affect the Phillips Curve? Some Evidence for Spain, December 2007

2167 Rainald Borck, Federalism, Fertility and Growth, December 2007

2168 Erkki Koskela and Jan König, Strategic Outsourcing, Profit Sharing and Equilibrium Unemployment, December 2007

2169 Egil Matsen and Øystein Thøgersen, Habit Formation, Strategic Extremism and Debt Policy, December 2007

2170 Torben M. Andersen and Allan Sørensen, Product Market Integration and Income Taxation: Distortions and Gains from Trade, December 2007

2171 J. Atsu Amegashie, American Idol: Should it be a Singing Contest or a Popularity Contest?, December 2007

2172 Patricia Apps and Ray Rees, Household Models: An Historical Perspective, December 2007

2173 Ben Greiner, Axel Ockenfels and Peter Werner, The Dynamic Interplay of Inequality and Trust - An Experimental Study, December 2007

2174 Michael Melvin and Magali Valero, The Dark Side of International Cross-Listing: Effects on Rival Firms at Home, December 2007

2175 Gebhard Flaig and Horst Rottmann, Labour Market Institutions and the Employment Intensity of Output Growth. An International Comparison, December 2007

2176 Alexander Chudik and M. Hashem Pesaran, Infinite Dimensional VARs and Factor Models, December 2007

2177 Christoph Moser and Axel Dreher, Do Markets Care about Central Bank Governor Changes? Evidence from Emerging Markets, December 2007 